\title{
Inhibitor protection of steel corrosion in acid solutions at high temperatures. A review. Part 2
}

\author{
Ya.G. Avdeev* and Yu.I. Kuznetsov \\ A.N. Frumkin Institute of Physical Chemistry and Electrochemistry, Russian Academy of \\ Sciences, Leninsky pr. 31, 119071 Moscow, Russian Federation \\ *E-mail: avdeevavdeev@mail.ru
}

\begin{abstract}
Data from scientific and patent literature concerning the protection of steels in acid solutions by unsaturated organic compounds (UCs) and formulations based on them at temperatures $(t)$ up to $250^{\circ} \mathrm{C}$ are generalized. It is noted that individual acetylenic compounds, unsaturated aldehydes, ketones and azomethines are rarely efficient in steel protection in $\mathrm{HCl}$ solutions at $t>100^{\circ} \mathrm{C}$. However, composite inhibitors based on some of these compounds allow their protective range to be expanded up to $t=250^{\circ} \mathrm{C}$ in certain cases. Data on the protection of various steels by such composite inhibitors is discussed. It is noted that high-temperature $\mathrm{HCl}$ solutions are the most acceptable corrosive environments for the application of such inhibitors. Issues related to the mechanism of the inhibitory effect of UCs are discussed. It is shown that the possibility of protecting steel at these high temperatures is a consequence of the unique inhibition mechanism of UCs that results from their ability to be chemisorbed on a metal surface and undergo deep chemical transformations to form protective polymer films. The drawbacks that limit the use of composite corrosion inhibitors containing UCs include their instability in hot corrosive media in the course of time, i.e., polymerization in the acid bulk that removes the inhibitor from the corrosive environment, which leads to its coking. Moreover, the UCs themselves and the additives used in combination with them are extremely toxic compounds. The bibliography includes 138 sources.
\end{abstract}

Keywords: high-temperature acid corrosion, steel, corrosion inhibitors, acidizing, hydrochloric acid, unsaturated organic compounds, acetylenic compounds, propargyl alcohol, unsaturated aldehydes, cinnamaldehyde, unsaturated ketones, azomethines.

Received: May 18, 2020. Published: June 30, 2020

doi: $\underline{10.17675 / 2305-6894-2020-9-3-5}$

\section{Introduction}

The first part of this review [1] discusses the most important fields of the practical application of acid solutions. They are used in the oil and gas industry for acid stimulation of oil- and gas-bearing strata and at metallurgical plants for removal of high-temperature scale from the surface of steel products. Analysis of literature data showed that when in operation, these process fluids, namely, solutions of $\mathrm{HCl}, \mathrm{H}_{2} \mathrm{SO}_{4}, \mathrm{H}_{3} \mathrm{PO}_{4}, \mathrm{H}_{3} \mathrm{CCOOH}$, $\mathrm{HCOOH}$ and citric acid, can be heated to temperatures of $t \geq 100^{\circ} \mathrm{C}$, which significantly 
increases their corrosiveness toward steel structures, pipelines and products they contact with. In such environments, steels corrode at tremendous rates, in some cases above $10 \mathrm{~kg} /\left(\mathrm{m}^{2} \cdot \mathrm{h}\right)$. Under high-temperature acid corrosion conditions, the operation of steel structures and pipelines is impossible without special protective measures. Metals in contact with hot solutions of both mineral and organic acids require protection. Apparently, the only acceptable way to protect steel under these conditions necessitates the use of corrosion inhibitors $(\mathrm{CI})$.

Table 1. Chemical composition of steels.

\section{Steel brand $\quad$ Content of elements in mass percent, $\%$}

Steel 1

Steel 3

Steel 5

Steel 10

Steel 20

Mild steel [18]

Mild steel [34]

Mild steel [39]

Carbon steel $36 \mathrm{G} 2 \mathrm{~S}$

Carbon steel [37]

AISI 1020

N80

J55

L80
0.07 C; $0.02 \mathrm{Si}$; $0.027 \mathrm{~S} ; 0.022 \mathrm{P}$; remainder Fe

$0.14-0.22 \mathrm{C}$; $0.15-0.33 \mathrm{Si} ; 0.40-0.65 \mathrm{Mn}$; up to $0.3 \mathrm{Cr}$; up to $0.30 \mathrm{Ni}$; up to 0.008 $\mathrm{N}$; up to $0.30 \mathrm{Cu}$; up to $0.05 \mathrm{~S}$; up to $0.04 \mathrm{P}$; up to $0.08 \mathrm{As}$; remainder $\mathrm{Fe}$ 0.28-0.37 C; up to 0.3 $\mathrm{Si}$; 0.5-0.8 Mn; up to 0.05 S; up to 0.04 P; remainder $\mathrm{Fe}$ 0.07-0.14 C; $0.17-0,37 \mathrm{Si} ; 0.35-0.65 \mathrm{Mn}$; up to $0.15 \mathrm{Cr}$; up to $0.25 \mathrm{Ni}$; up to 0.25 $\mathrm{Cu}$; up to $0.04 \mathrm{~S}$; up to $0.035 \mathrm{P}$; up to $0.08 \mathrm{As}$; remainder $\mathrm{Fe}$

0.17-0.24 C; $0.17-0.37 \mathrm{Si} ; 0.35-0.65 \mathrm{Mn}$; up to $0.25 \mathrm{Cr}$; up to $0.30 \mathrm{Ni}$; up to 0.30 $\mathrm{Cu}$; up to $0.04 \mathrm{~S}$; up to $0.035 \mathrm{P}$; up to $0.08 \mathrm{As}$; remainder $\mathrm{Fe}$ $0.270 \mathrm{C} ; 0.340 \mathrm{Mn} ; 0.080 \mathrm{Si} ; 0.006 \mathrm{~S} ; 0.008 \mathrm{P}$; remainder Fe $0.18 \mathrm{C} ; 0.50 \mathrm{Mn} ; 0.21 \mathrm{Si} ; 0.05 \mathrm{~S} ; 0.04 \mathrm{P}$; remainder Fe $0.14 \mathrm{C} ; 0.35 \mathrm{Mn} ; 0.17 \mathrm{Si} ; 0.025 \mathrm{~S} ; 0.03 \mathrm{P}$; remainder Fe $0.47 \mathrm{C} ; 0.019 \mathrm{Si} ; 0.70 \mathrm{Mn} ; 0.06 \mathrm{Ni} ; 0.05 \mathrm{Cr} ; 0.030 \mathrm{~S} ; 0.022 \mathrm{P}$; remainder Fe $0.14 \mathrm{C} ; 0.35 \mathrm{Mn} ; 0.17 \mathrm{Si}$; 0.025 S; 0.03 P; remainder Fe 0.17-0.23 C; $0.30-0.60 \mathrm{Mn}$; up to $0.05 \mathrm{~S}$; up to $0.04 \mathrm{P}$; remainder Fe 0.34-0.38 C; $0.20-0.35 \mathrm{Si} ; 1.45-1.7 \mathrm{Mn}$; up to $0.02 \mathrm{P}$; up to $0.015 \mathrm{~S}$; up to $0.15 \mathrm{Cr}$; $0.11-0.16 \mathrm{~V}$; remainder Fe

0.34-0.39 C; $0.20-0.35 \mathrm{Si} ; 1.25-1.5 \mathrm{Mn}$; up to $0.02 \mathrm{P}$; up to $0.015 \mathrm{~S}$; up to $0.15 \mathrm{Cr}$; up to $0.20 \mathrm{Ni}$; up to $0.20 \mathrm{Cu}$; remainder $\mathrm{Fe}$

0.15-0.20 C; up to $1.00 \mathrm{Si}$; $0.25-1.0 \mathrm{Mn}$; up to $0.02 \mathrm{P}$; up to $0.010 \mathrm{~S}$; $12.0-14.0 \mathrm{Cr}$; up to $0.20 \mathrm{Ni}$; up to $0.20 \mathrm{Cu}$; remainder $\mathrm{Fe}$ 
We discussed the methodological and technical issues of studying the corrosion of steels and their electrochemical behavior in acid solutions at elevated temperatures $(t)$, both in the absence and in the presence of CIs, in the first part of this review. The chemical composition of steels discussed in this review is given in Table 1.

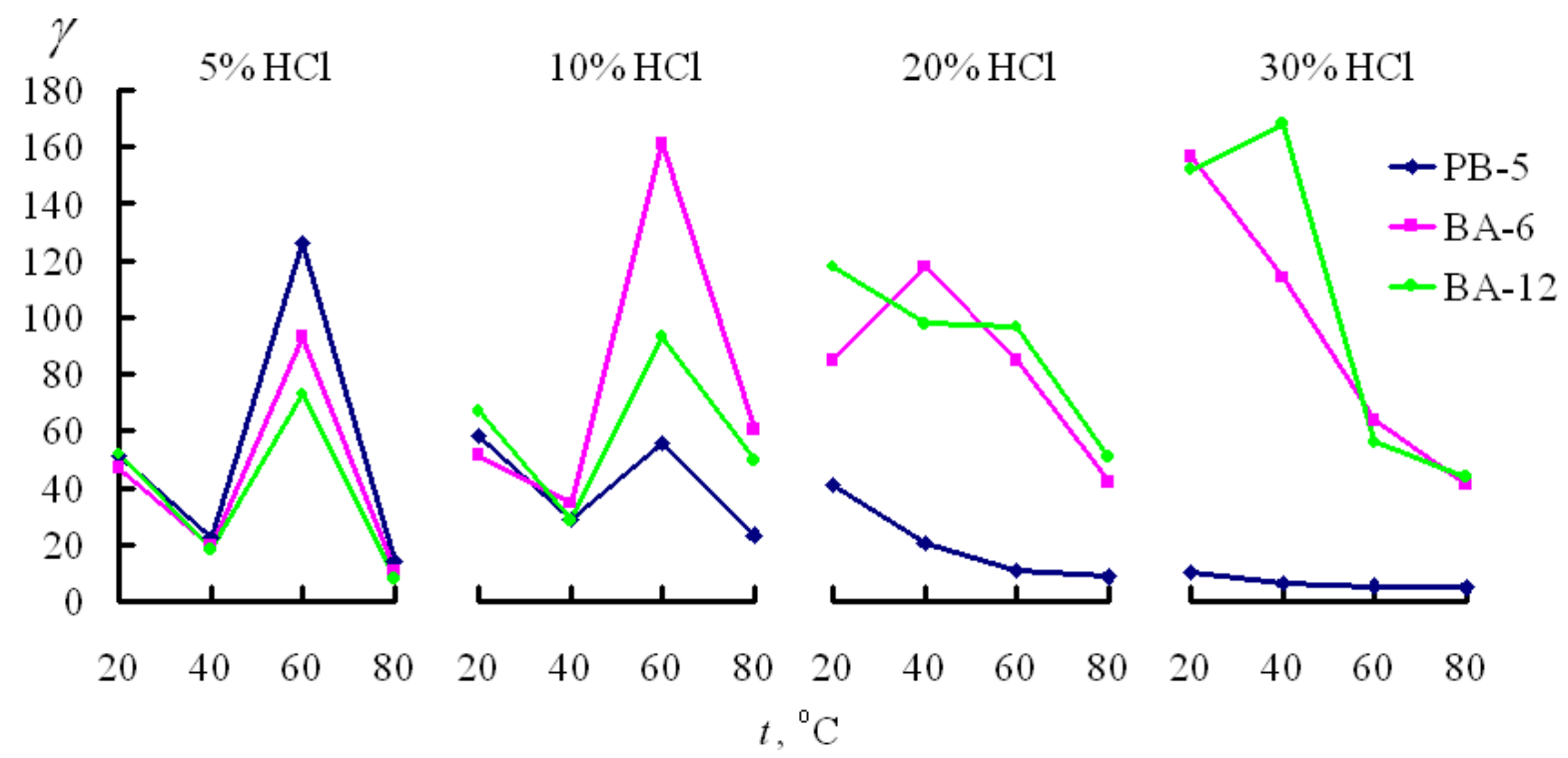

Figure 1. Steel corrosion inhibition factors for Steel 3 in $\mathrm{HCl}$ solutions with addition of $0.5 \%$ PB-5, BA-6, BA-12.

One of the first studies on the effect of the corrosive medium temperature on the protective effect of CIs was performed by S.A. Balezin [2]. Studies on the protective effect of CIs consisting of condensation products, namely, urotropine and aniline (PB-5), benzylamine and urotropine (BA-6) or benzylamine and paraform (BA-12), in the corrosion of Steel 3 in $\mathrm{HCl}$ solutions showed that with an increase in $t$, the protection coefficients decrease or pass through a maximum at $60^{\circ} \mathrm{C}$, depending on the acid solution concentration (Figure 1). The observed effect is explained by the fact that inhibitors are desorbed from the surface of steel at $t>60^{\circ} \mathrm{C}$ and thus cease to protect the metal.

It was later shown [3] that some CIs called high-temperature corrosion inhibitors (HCIs) demonstrate the maximum efficiency of protective action at $t>60^{\circ} \mathrm{C}$, which ensures a significant inhibition of corrosion of steels even at higher $t$ values. For example, in the protection of Steel 5 in 16\% $\mathrm{HCl}$ with industrial inhibitors PB-5 and I-1-A (a mixture of polyalkylpyridines) and their formulations with urotropine, the temperature maximum of the protective effect lies at $t=60-70^{\circ} \mathrm{C}$ only for PB-5 itself. For I-1-A, urotropine and mixed inhibitors, this maximum is at $t=80-90^{\circ} \mathrm{C}$, which allows one to attribute them to HCIs (Figure 2a). An important rule of thumb was formulated that opens up the possibility of creating mixed HCIs: " $\ldots$ the temperature maximum of the inhibitory effect of a mixture consisting of two inhibitors with different temperature maxima approaches the highertemperature maximum. If the temperature maxima for two inhibitors are the same, then the 
maxima do not shift." In fact, even the first studies on the protective effect of inhibitors versus $t$ made it possible to distinguish a group of HCIs and suggest ways to increase their efficiency by creating mixtures. It is important for practical application of HCIs that the temperature maximum of their protective effect be higher and that the protective effect after achieving the maximum decrease as slowly as possible. Otherwise, the temperature region where the inhibitor provides the necessary protection would be limited by its temperature maximum.

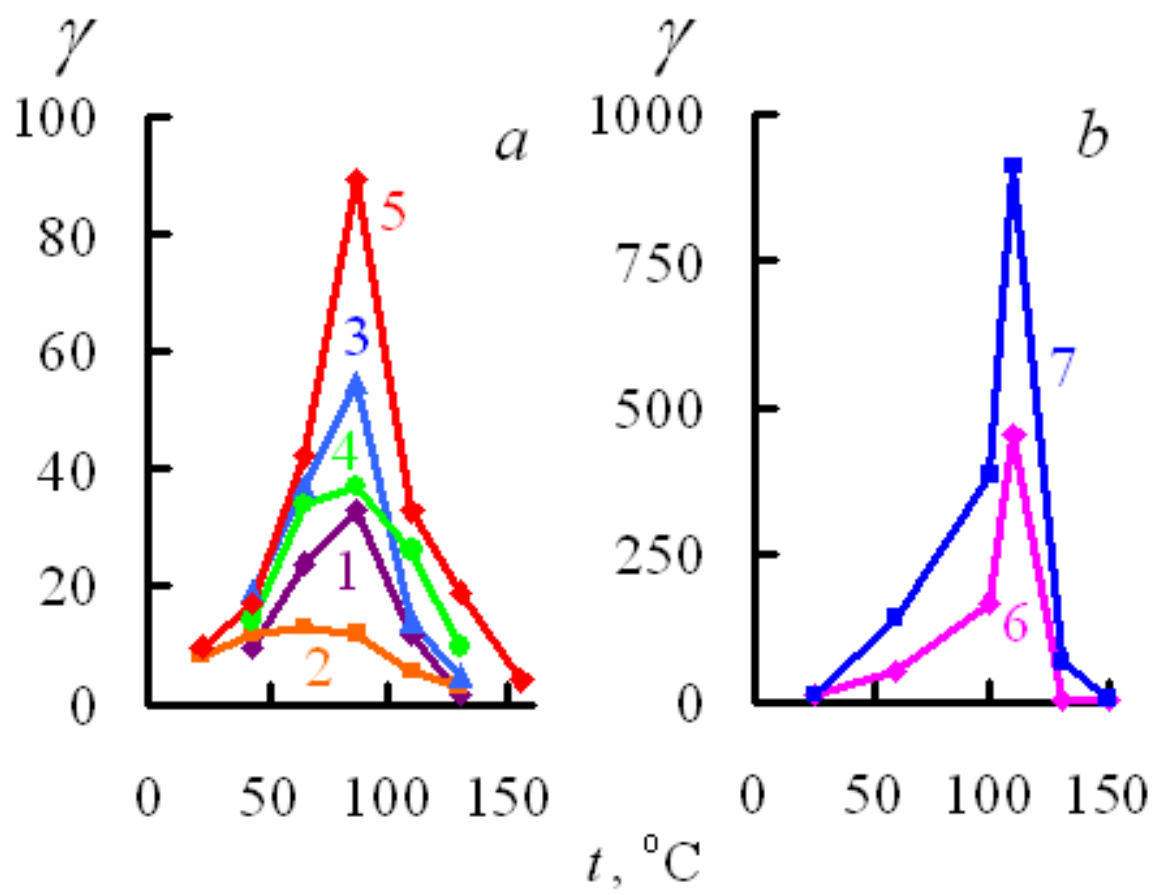

Figure 2. Steel corrosion inhibition factors for Steel 5 in $16 \% \mathrm{HCl}(300 \mathrm{~atm})(a)$ with addition of $1 \%$ urotropine (1), $1 \%$ PB-5 (2), $1 \%$ I-1-A (3), 1\% PB-5 + 0.5\% urotropine (4), 0.4\% I-1-A $+0.8 \%$ urotropine (5) and for low carbon steelin $4 \mathrm{M} \mathrm{HCl}(b)$ with addition of $30 \mathrm{MM} \mathrm{PA} \mathrm{(6),}$ 30 мM hex-1-yn-3-ol (7).

We can tentatively distinguish two approaches to the creation of HCIs for the protection of steels in acid solutions. It is assumed that organic compounds with different mechanisms of action, namely, unsaturated compounds (UC) and nitrogen-containing heterocycles mainly represented by triazoles, can be used as the basis for HCIs. The use of these two groups of compounds alone as HCIs is not justified. On the other hand, mixed CIs developed on the basis of these compounds are capable of protecting steel against acid corrosion in a wide range of elevated temperatures.

The formulations contain both organic and inorganic additives. These additives may not necessarily be HCIs by themselves. Sometimes the content of an additive in a formulation may be higher than that of a high-temperature component. We will discuss these cases in the discussion of composite CIs. 
The following unsaturated organic compounds will be considered as HCIs in this review: acetylenic compounds, unsaturated aldehydes, ketones and azomethines. It is important to consider not only the effect of these compounds on the corrosion process, but also the possibility of improving their protective effect by creating mixed CIs on their basis. It is important to consider the state-of-the-art concepts of the protective mechanism of unsaturated organic compounds, which is necessary for the development of a scientific approach to the use of these compounds and for intentional creation of formulations based on them.

The general topics of steel protection in acid solutions by acetylenic compounds (AC), unsaturated aldehydes, ketones and azomethines were considered in reviews [4-6]. Some specific features of the mechanism of their inhibitory action are also discussed there. In this review, priority is given to the generalization and analysis of topics related to the use of these CIs in the high-temperature corrosion of steels.

\section{Protection of steels in acid solutions by unsaturated organic compounds}

Early studies in the field of HCI development are related to acetylenic compounds (ACs). Determination of the effect of a wide range of such compounds (hydrocarbons, alcohols, chlorinated derivatives, ethers and esters, quaternary ammonium salts) on the corrosion of mild steel in $4 \mathrm{M} \mathrm{HCl}\left(25-100^{\circ} \mathrm{C}\right)$ showed that non-branched primary and secondary alcohols $\mathrm{HC} \equiv \mathrm{C}-\mathrm{CH}(\mathrm{R})-\mathrm{OH}$ provide the highest corrosion inhibition [7]. The efficiency of protection by alcohols $(30 \mathrm{mM})$ increases in the series of radicals $-\mathrm{R}$ : $-\mathrm{H}<-\mathrm{CH}_{3}<$ $-\mathrm{CH}_{2}-\mathrm{CH}_{3}<-\left(\mathrm{CH}_{2}\right)_{2}-\mathrm{CH}_{3}$ but decreases somewhat on passage to $-\left(\mathrm{CH}_{2}\right)_{5}-\mathrm{CH}_{3}$, which is explained by the poorer solubility of the latter in comparison with the other alcohols. For all the compounds studied, the protective effect increases with an increase in $t$. The corrosion inhibition coefficient of the weakest CI in this series, propargyl alcohol (PA), is within 11167 , while that of the strongest one, hex-1-yn-3-ol, is within 12-525. The temperature maximum of the efficiency of both CIs lies at $t=110^{\circ} \mathrm{C}$; at higher temperatures, the protection of steel by these compounds decreases considerably (Figure $2 \mathrm{~b}$ ). In the presence of these inhibitors, the $k$ of steel is within 1.0-13.8 and $0.88-4.4 \mathrm{~g} /\left(\mathrm{m}^{2} \cdot \mathrm{h}\right)$ against $10.7-2310 \mathrm{~g} /\left(\mathrm{m}^{2} \cdot \mathrm{h}\right)$ in the background solution. Tertiary alcohols $\mathrm{HC} \equiv \mathrm{C}-\mathrm{CR}^{\prime}\left(\mathrm{R}^{\prime \prime}\right)-\mathrm{OH}$ and diols $\mathrm{HO}-\mathrm{CR}^{\prime}\left(\mathrm{R}^{\prime \prime}\right)-\mathrm{C} \equiv \mathrm{C}-\mathrm{CR}^{\prime}\left(\mathrm{R}^{\prime \prime}\right)-\mathrm{OH}$ provide much poorer protection. PA esters are inferior to PA in corrosion inhibition at $100^{\circ} \mathrm{C}$. For example, the corrosion inhibition coefficient of propargyl ester of caproic acid $\left(\mathrm{HC} \equiv \mathrm{C}-\mathrm{CH}_{2}-\mathrm{O}-\mathrm{CO}-\mathrm{C}_{5} \mathrm{H}_{11}\right)$ is $\gamma=21$. In contrast, an ether, $\mathrm{HC} \equiv \mathrm{C}-\mathrm{CH}_{2}-\mathrm{O}-\mathrm{CH}_{2}-\mathrm{C} \equiv \mathrm{CH}$, exceeds PA in terms of protection. Addition of $15 \mathrm{mM}$ of this compound at $t=25-100^{\circ} \mathrm{C}$ provides $k=0.90-12.8 \mathrm{~g} /\left(\mathrm{m}^{2} \cdot \mathrm{h}\right)$. Unsatisfactory steel protection results are demonstrated by acetylenic hydrocarbons with a terminal triple bond: acetylene, hex-1-yne, oct-1-yne, and dec-1-yne. Acetylene, the most efficient of them, slows down corrosion 27fold at $25^{\circ} \mathrm{C}$ but only 2.3 -fold at $100^{\circ} \mathrm{C}$. At $100^{\circ} \mathrm{C}$, its chloro derivatives $\left(\mathrm{HC} \equiv \mathrm{C}-\mathrm{CH}_{2}-\mathrm{Cl}\right.$ and 
$\left.\mathrm{ClC} \equiv \mathrm{C}-\mathrm{CH}_{2}-\mathrm{OH}\right)$ and substituted propargylamines in the form of hydrobromic salts $\left(\left[\mathrm{HC} \equiv \mathrm{C}-\mathrm{CH}_{2}-\mathrm{NH}_{2} \mathrm{R}\right] \mathrm{Br}\right)$ are inferior to $\mathrm{PA}$ in protection. Data similar in many respects are presented in [8] where the effect of $\mathrm{AC}$ structure (39 compounds) on the corrosion inhibition of AISI 1020 steel in $10 \% \mathrm{HCl}\left(66-93^{\circ} \mathrm{C}\right)$ is discussed.

In parallel with ACs, several industrial CIs were studied: 1.0\% PB-5, 0.5\% BA-6, $1.0 \%$ I-1-A, and $0.5 \%$ catapine- $\mathrm{K}\left(\left[\mathrm{H}_{3} \mathrm{C}\left(\mathrm{CH}_{2}\right)_{n} \mathrm{CH}_{2} \mathrm{C}_{6} \mathrm{H}_{4} \mathrm{CH}_{2} \mathrm{NC}_{5} \mathrm{H}_{5}\right] \mathrm{Cl}, p\right.$-alkylbenzylpyridinium chloride, where $n=4-6$ ) [9]. In the range of $t=25-100^{\circ} \mathrm{C}$, the corrosion inhibition coefficients of steel by these CIs increase, which is evidence of their high-temperature properties. In $15 \% \mathrm{HCl}\left(100^{\circ} \mathrm{C}\right)$, the corrosion rate of Steel 10 is $2860 \mathrm{~g} /\left(\mathrm{m}^{2} \cdot \mathrm{h}\right)$, while it is $46.2 \mathrm{~g} /\left(\mathrm{m}^{2} \cdot \mathrm{h}\right)$ in the presence of PB-5, $28.1 \mathrm{~g} /\left(\mathrm{m}^{2} \cdot \mathrm{h}\right)$ with BA-6, $6.3 \mathrm{~g} /\left(\mathrm{m}^{2} \cdot \mathrm{h}\right)$ with I-1-A, and $5.1 \mathrm{~g} /\left(\mathrm{m}^{2} \cdot \mathrm{h}\right)$ with catapine-K. For the last two CIs, the results are better than for $0.3 \%$ PA $\left(k=13.8 \mathrm{~g} /\left(\mathrm{m}^{2} \cdot \mathrm{h}\right)\right)$ but poorer than for $0.3 \%$ hex-1-yn-3-ol $\left(k=4.4 \mathrm{~g} /\left(\mathrm{m}^{2} \cdot \mathrm{h}\right)\right)$. Despite the optimistic results on the efficiency of I-1-A and catapine-K in protecting steel in $\mathrm{HCl}$ solution at $t=100^{\circ} \mathrm{C}$, limitations in their practical application have been demonstrated. Even at room temperature in $28 \% \mathrm{HCl}$, both CIs cease to protect the metal after 4 days of corrosion tests, whereas the protective effect of PA increases for 20 days and is maintained for at least 30 days.

In $\mathrm{H}_{2} \mathrm{SO}_{4}$ solutions, ACs either stimulate or slightly slow down steel corrosion [9], which makes their individual application in these media unpromising. Podobayev et al. [9] attributed the observed stimulating effect to the formation of complex compounds of ACs with iron accelerating the anodic reaction. Later, it was shown by the voltammetry method $[10,11]$ that the low protective effect of ACs in the corrosion of steels in $\mathrm{H}_{2} \mathrm{SO}_{4}, \mathrm{H}_{3} \mathrm{PO}_{4}$ and $\mathrm{HClO}_{4}$ solutions results from their reduction on the metal surface, which stimulates the cathodic process. Of ACs, anomalously high protection of Steel 10 in $5-25 \% \mathrm{H}_{2} \mathrm{SO}_{4}\left(80^{\circ} \mathrm{C}\right)$ is provided by $0.2 \%$ dipropargyl thioether in the presence of which $k=0.22-0.28 \mathrm{~g} /\left(\mathrm{m}^{2} \cdot \mathrm{h}\right)$. Under the same conditions in the background solution, $k_{0}=59-231 \mathrm{~g} /\left(\mathrm{m}_{2} \cdot \mathrm{h}\right)$. Unfortunately, information on the protection of steels by these CIs in $\mathrm{H}_{2} \mathrm{SO}_{4}$ solutions at higher temperatures is missing [9].

A systematic search for HCIs among halogenated AC derivatives showed the futility of this approach [12]. In $4 \mathrm{M} \mathrm{HCl}\left(100^{\circ} \mathrm{C}\right)$, the corrosion of Steel $10\left(k_{0}=2756 \mathrm{~g} /\left(\mathrm{m}^{2} \cdot \mathrm{h}\right)\right)$ is hindered 40-fold by $15 \mathrm{mM}$ PA, 2.7-fold by $15 \mathrm{mM}$ propargyl chloride, 3.5-fold by $15 \mathrm{mM}$ propargyl bromide, and 78-fold by $15 \mathrm{mM}$ propargyl iodide. With the same concentrations of halopropargyl alcohols, the opposite dependence is observed: $\gamma\left(\mathrm{ClC} \equiv \mathrm{C}-\mathrm{CH}_{2}-\mathrm{OH}\right)=54$, $\gamma\left(\mathrm{BrC} \equiv \mathrm{C}-\mathrm{CH}_{2}-\mathrm{OH}\right)=24$ and $\gamma\left(\mathrm{CI} \equiv \mathrm{C}-\mathrm{CH}_{2}-\mathrm{OH}\right)=3.1$. Despite the high protective effect of propargyl iodide, the formulation of $7.5 \mathrm{mM}$ PA and $7.5 \mathrm{~mm} \mathrm{KI}$ inhibits corrosion more strongly $(\gamma=135)$.

AC ethers were widely studied as HCIs. Among nine PA ethers with various structures, the corrosion of steel $3\left(k_{0}=255-3000 \mathrm{~g} /\left(\mathrm{m}^{2} \cdot \mathrm{h}\right)\right)$ in $4 \mathrm{M} \mathrm{HCl}\left(60-100^{\circ} \mathrm{C}\right)$ is successfully inhibited by 


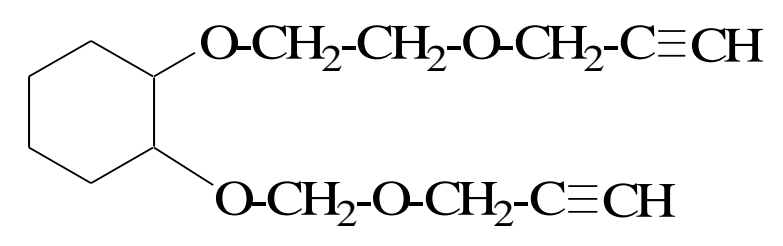

$\left.\left(k=1.3-4.0 \mathrm{~g} /\left(\mathrm{m}^{2} \cdot \mathrm{h}\right)\right)\right)$ and

$$
\mathrm{HC} \equiv \mathrm{C}-\mathrm{CH}_{2}-\mathrm{O}-\mathrm{CH}_{2}-\mathrm{CH}_{2}-\mathrm{O}-\mathrm{CH}_{2}-\mathrm{C} \equiv \mathrm{CH}
$$

$\left(k=1.3-3.7 \mathrm{~g} /\left(\mathrm{m}^{2} \cdot \mathrm{h}\right)\right)$ [13]. Of ten phosphinic acid esters $(15 \mathrm{mM})$, Steel $1 \quad\left(k_{0}=\right.$ $\left.2861 \mathrm{~g} /\left(\mathrm{m}^{2} \cdot \mathrm{h}\right)\right)$ is most efficiently protected in $15 \% \mathrm{HCl}\left(100^{\circ} \mathrm{C}\right)$ by benzylphosphinic acid dipropargyl ester $\left(k=16.5 \mathrm{~g} /\left(\mathrm{m}^{2} \cdot \mathrm{h}\right)\right)$ and methylcyclohexylphosphinic acid dipropargyl ester $\left(k=18 \mathrm{~g} /\left(\mathrm{m}^{2} \cdot \mathrm{h}\right)\right)$, which is worse than with PA $\left(k=13.8 \mathrm{~g} /\left(\mathrm{m}^{2} \cdot \mathrm{h}\right)\right)[14]$. In $4 \mathrm{M} \mathrm{HCl}\left(100^{\circ} \mathrm{C}\right)$, Steel $10\left(k_{0}=2175 \mathrm{~g} /\left(\mathrm{m}^{2} \cdot \mathrm{h}\right)\right)$ is protected by 1-phenyl-2-propargyloxypropane that slows down corrosion 369-fold [15]. The propargyl ether of phenol is of interest. With addition of 10 vol.\% ethanol, it protects cold-rolled electrotechnical anisotropic thin-sheet steel (GOST 21427.1-75), nickel (99.0\%) and cobalt $(99.98 \%)$ in $5 \mathrm{M} \mathrm{HCl}\left(92^{\circ} \mathrm{C}\right)$, providing $k=6.0,0.4$ and $0.4 \mathrm{~g} /\left(\mathrm{m}^{2} \cdot \mathrm{h}\right)$, which corresponds to $\gamma=270,420$ and 125 , respectively [16].

It is noted that a transition from ACs to ethylenic compounds with similar structures reduces the protective effect of CIs. In fact, methylcyclohexylphosphinic acid diallyl ester in $4 \mathrm{M} \mathrm{HCl}\left(100^{\circ} \mathrm{C}\right)$ slows down the corrosion of Steel 10 by a factor of 4.1, i.e., 39 times worse than methylcyclohexylphosphinic acid dipropargyl ester [14]. Unsaturated furfuryl alcohol poorly slows down steel corrosion at elevated temperatures [17]. Addition of $80 \mathrm{mM}$ furfuryl alcohol provides $90 \%$ protection of $\mathrm{N} 80$ steel in $15 \% \mathrm{HCl}$ at $30^{\circ} \mathrm{C}$, but only $72 \%$ at $110^{\circ} \mathrm{C}$. The protection of steel by saturated and acetylenic alcohols differs more significantly. In $15 \% \mathrm{HCl}\left(105^{\circ} \mathrm{C}\right), 1 \%$ of octan- 1 -ol, despite a substantially larger molecular weight, provides a degree of protection $Z=82 \%$ on mild steel $\left(k_{0}=380 \mathrm{~g} /\left(\mathrm{m}^{2} \cdot \mathrm{h}\right)\right)$, while $1 \%$ of PA provides $Z=99 \%$ [18].

The synthesized ACs with rather complex structures, such as diacetylenic ethers [19], allylacetylenes [20], acetyleneamines [21], halogenated alcohols [22], and nitrogencontaining heterocyclic structures [23-29], are capable of providing efficient protection of steel in $\mathrm{HCl}$ solutions, but their applicability in these media at $t>80^{\circ} \mathrm{C}$ was not studied. Allylacetylene derivatives can slow down the corrosion of low-carbon steel in $\mathrm{H}_{2} \mathrm{SO}_{4}$ solutions in the range of $t=40-80^{\circ} \mathrm{C}$ [30]. Despite the fact that various ACs with complex chemical structures were studied as CIs, studying the simplest one, PA, for the needs of the oil and gas industry remains of current interest [31-33].

Unsaturated aldehydes and ketones constitute a less studied group of UCs used to protect steels in hot $\mathrm{HCl}$. Most often, the protective effect of these compounds in individual form is weak. In fact, cinnamaldehyde (CA) in $2 \mathrm{M} \mathrm{HCl}\left(95^{\circ} \mathrm{C}\right)$ at $C=10 \mathrm{mM}$ slows down the corrosion of mild steel $\left(k_{0}=995 \mathrm{~g} /\left(\mathrm{m}^{2} \cdot \mathrm{h}\right)\right)$ only 10 -fold. $\alpha$-Amyl-CA, citral and crotonic aldehyde are less efficient in steel protection [34]. At a higher CA content, it slows down the 
corrosion more strongly [35]. In $20 \% \mathrm{HCl}\left(90^{\circ} \mathrm{C}\right), 1 \%$ of CA provides $k=6.3 \mathrm{~g} /\left(\mathrm{m}^{2} \cdot \mathrm{h}\right)$ on N80 steel. Ketones similar in structure to CA, benzalacetone and chalcone, provide $k$ values of 116 and $413 \mathrm{~g} /\left(\mathrm{m}^{2} \cdot \mathrm{h}\right)$ that are significantly worse. At $105^{\circ} \mathrm{C}$ in $15 \% \mathrm{HCl}$, disalicylidene acetone $(4000 \mathrm{ppm})$ can slow down the corrosion of $\mathrm{N} 80$ steel $\left(k_{0}=2.6 \mathrm{~g} /\left(\mathrm{m}^{2} \cdot \mathrm{h}\right)\right)$ by a factor up to 80 [36].

Nitrogen-containing derivatives of unsaturated aldehydes were also studied as HCIs. In $15 \% \mathrm{HCl}\left(110^{\circ} \mathrm{C}\right)$, addition of $1500 \mathrm{ppm}$ 1-cinnamylidene-3-thiocarbohydrazide provides $Z=98.2 \%$ for carbon steel $\left(k_{0}=12.8 \mathrm{~kg} /\left(\mathrm{m}^{2} \cdot \mathrm{h}\right)\right)$, whereas $1500 \mathrm{ppm}$ of $1,1^{\prime}-$ dicinnamylidene-3-thiocarbohydrazide provides a higher value, 99.0\% [37]. Addition of $5000 \mathrm{ppm}$ 2,4-dicinnamylidene aminophenylene $(Z=99.75 \%)$ is even more efficient under these conditions [38]. In $15 \% \mathrm{HCl}\left(105^{\circ} \mathrm{C}\right)$ on mild steel $\left(k_{0}=39.5 \mathrm{~kg} /\left(\mathrm{m}^{2} \cdot \mathrm{h}\right)\right)$ in the presence of $5000 \mathrm{ppm}$ 1-decene-4-phenyl-thiosemicarbazide, $Z=96.0 \%$, while on N80 steel $\left.\left(k_{0}=1.6 \mathrm{~kg} /\left(\mathrm{m}^{2} \cdot \mathrm{h}\right)\right)\right)$ the value is $Z=90.8 \%$ [39].

Benzoyl allyl alcohol $(18 \mathrm{mM})$ in $28.3 \% \mathrm{HCl}\left(94^{\circ} \mathrm{C}\right)$ slows down the corrosion of J55 steel $\left(k_{0}=4.5 \mathrm{~kg} /\left(\mathrm{m}^{2} \cdot \mathrm{h}\right)\right)$ to $\left.41 \mathrm{~g} /\left(\mathrm{m}^{2} \cdot \mathrm{h}\right)\right)$, which corresponds to $\gamma=110[40]$.

Scattered data on the protection of steels in acid solutions at elevated temperatures by individual UCs measured by the mass loss of steel samples have been generalized. Various AC groups, unsaturated aldehydes, ketones and their nitrogen-containing derivatives can be used to protect steels in acids. The use of these compounds to protect steels in $\mathrm{HCl}$ solutions is acceptable, but only some of them can be used to inhibit corrosion in $\mathrm{H}_{2} \mathrm{SO}_{4}$ solutions because of the danger of corrosion stimulation by these compounds. The corrosion rates of steels in the presence of individual alloys at $t \geq 100^{\circ} \mathrm{C}$ in $\mathrm{HCl}$ solutions may remain high, which significantly limits their industrial application.

The protection of steels under high-temperature corrosion conditions can be improved by synthesizing new UCs that may potentially have higher inhibitory efficiency. Unfortunately, this path is not quite realistic, since the cost of such compounds increases incomparably with the increase in their protective effects. In addition, the temperature maximum of the efficiency of individual UCs is unlikely to exceed $t=110^{\circ} \mathrm{C}$, which does not allow us to hope for an efficient protection of steel by these compounds at higher temperatures. The only acceptable solution to this problem is to create mixed inhibitors, whose protective effect is higher, based on available UCs. This technique was successfully used to create industrial acid CIs [41, 42].

\section{Composite high-temperature corrosion inhibitors based on unsaturated organic compounds}

The main approach used to determine the prospects of CI mixtures being created is to estimate the mutual effect of their components, which can be antagonistic, additive, or synergistic. There are several approaches to the quantitative description of the mutual effect of the components of inhibitor mixtures. They are covered in a review [43]. When a HCI is developed, this approach is often unpromising, since determining the protective effect of 
individual mixture components at $t>100^{\circ} \mathrm{C}$ is either impractical or impossible as the $k$ values of metals are extremely high in their presence, while one of the components may be not an HCI. Moreover, for the same reasons, the $k$ of steel in background media is not determined in some studies but is considered to obviously fail to meet the requirements for the operation of steels. In practice-oriented studies, it is required that the composite inhibitor slow down steel corrosion to values acceptable in operation. From our point of view, in the estimation of HCI properties it is most important to know the temperature range in which efficient protection of steels is possible, as well as the maximum $k$ of steel that is acceptable in this temperature range.

In the beginning of studies on ACs as CIs, an interesting effect was noted that the protective effect of acetylene alcohols with linear structures is enhanced when they are mixed together. In fact, in $15 \% \mathrm{HCl}$ in the presence of $0.2 \% \mathrm{PA}$, the $k$ of steel is $208 \mathrm{~g} /\left(\mathrm{m}^{2} \cdot \mathrm{h}\right)$, while in the presence of $0.2 \%$ heptynol it is $1.6 \mathrm{~g} /\left(\mathrm{m}^{2} \cdot \mathrm{h}\right)$. Under the same conditions, in the presence of $0.2 \%$ PA+heptynol $(1: 1), k=0.21 \mathrm{~g} /\left(\mathrm{m}^{2} \cdot \mathrm{h}\right)$ [4]. The observed effect was related to the fact that a higher-molecular alcohol that potentially offers better protection is poorly soluble in acid solutions. The presence of a lower-molecular alcohol in the mixture favors its better solubility, which ultimately increases the protective effect. The possibility of enhancing the protective effect of aldehydes with different structures by creating their mixtures was noted. However, the nature of this phenomenon is more complex [44].

The protective effect of acetylenic alcohols (PA, hex-1-yn-3-ol, 6-methylhept-1-yn-3ol, non-1-yn-3-ol, undec-1-yn-3-ol, dodec-1-yn-3-ol) passes through a maximum with an increase in the number of carbon atoms in their structure (Figure 3a). This behavior of inhibitors is explained by the fact that with an increase in the number of carbon atoms in the alcohol molecule, its potential ability to protect the metal increases but solubility decreases, which reduces the $\mathrm{CI}$ content in the corrosive environment. It was found possible to increase the protective effect of relatively high-molecular alcohols by combining them with organic solvents. In fact, organic solvents $(5 \%$ vol.) are arranged in the order of enhancing the protection of Steel 20 in $5 \mathrm{M} \mathrm{HCl}\left(95^{\circ} \mathrm{C}\right)$ in the presence of $10 \mathrm{mM}$ dodec-1-yhn-3-ol as follows: ethylene glycol < piperidine $<$ tetrahydrofuran $<$ acetone $<$ methyl alcohol $<$ ethyl alcohol $<$ acetaldehyde. Under these conditions, $\gamma=1.5$ for dodec-1-yn-3-ol itself and 813 for its mixture with acetaldehyde. An increase in the solvent content in the corrosive medium to 7 vol.\% enhances the effect of ACs (Figure 3b) [45]. The addition of organic solvents such as acetic and crotonic aldehydes at elevated temperatures improves the protective effect of not only ACs, hex-1-yn-3-ol and dodec-1-yn-3-ol, but also of a nitrogen-containing organic inhibitor, BA-6 (Table 2). It is more promising to enhance the protective effect of mixtures of ACs with BA- 6 by addition of acetic or crotonic aldehyde. It is important that the most efficient formulation, dodec-1-yn-3-ol+BA-6+acetic aldehyde, preserves the tensile, compressive, and bending strength of steel 3 by $85-92 \%$ at $120^{\circ} \mathrm{C}[46,47]$. 
Table 2. Corrosion rates $\left(k, \mathrm{~g} /\left(\mathrm{m}^{2} \cdot \mathrm{h}\right)\right)$ of Steel 20 in $15 \% \mathrm{HCl}$ [46].

\begin{tabular}{|c|c|c|c|c|c|c|}
\hline \multirow{2}{*}{ Inhibitor* } & \multicolumn{6}{|c|}{ Temperature, ${ }^{\circ} \mathrm{C}$} \\
\hline & 110 & 120 & 130 & 140 & 150 & 160 \\
\hline- & 5140 & 7450 & 9540 & 12110 & 17170 & 20110 \\
\hline $0.4 \%$ Hex-1-yn-3-ol & 41 & 442 & - & - & - & - \\
\hline 0.4\% Dodec-1-yn-3-ol & 33 & 342 & - & - & - & - \\
\hline $0.5 \%$ BA- 6 & 45 & 155 & - & - & - & - \\
\hline \multicolumn{7}{|c|}{$0.9 \mathrm{M}$ Acetic aldehyde } \\
\hline- & 33 & 144 & 2125 & - & - & - \\
\hline $0.4 \%$ Hex-1-yn-3-ol & 28 & 113 & 184 & - & - & - \\
\hline 0.4\% Dodec-1-yn-3-ol & 25 & 92 & 125 & - & - & - \\
\hline $0.5 \%$ BA-6 & 18 & 32 & 130 & 220 & - & - \\
\hline $\begin{array}{l}0.4 \% \text { Hex-1-yn-3-ol } \\
+0.5 \% \text { BA- } 6\end{array}$ & 10 & 35 & 50 & 89 & 284 & - \\
\hline $\begin{array}{l}0.4 \% \text { Dodec-1-yn-3-ol } \\
+0.5 \% \text { BA-6 }\end{array}$ & 3 & 14 & 25 & 45 & 62 & 185 \\
\hline \multicolumn{7}{|c|}{$1 \%$ Crotonaldehyde } \\
\hline- & 38 & 160 & 2040 & - & - & - \\
\hline $0.4 \%$ Hex-1-yn-3-ol & - & 22 & 125 & 160 & - & - \\
\hline 0.4\% Dodec-1-yn-3-ol & - & 18 & 101 & 141 & - & - \\
\hline $0.5 \%$ BA- 6 & 19 & 34 & 115 & 214 & - & - \\
\hline $\begin{array}{l}0.4 \% \text { Hex-1-yn-3-ol } \\
+0.5 \% \text { BA- } 6\end{array}$ & - & 8 & 22 & 72 & 118 & 250 \\
\hline $\begin{array}{l}0.4 \% \text { Dodec-1-yn-3-ol } \\
+0.5 \% \text { BA-6 }\end{array}$ & - & 5 & 15 & 50 & 68 & 190 \\
\hline
\end{tabular}

Efficient protection of various steels in $\mathrm{HCl}$ solutions can be achieved using alkali metal iodides $[48,49]$, but they are used more often as synergistic additives to organic inhibitors of various nature, which significantly improves the corrosion inhibition by these compounds [50-60]. Judging by the ranges of $t$ in which these inhibitor formulations were studied, their use is intended at temperatures substantially lower than $100^{\circ} \mathrm{C}$. Considering the high cost of alkali metal iodides, the use of such formulations in acid solutions in this $t$ range is not justified economically since many cheaper compounds and formulations are known that do not contain iodides but provide the required protection of metals under these conditions 
[41, 42, 61-70]. In contrast, at elevated temperatures where the selection of CIs for acid media is difficult, addition of metal iodides to mixed CIs is justified and sometimes provides the only possibility to create a product with the required protective properties.
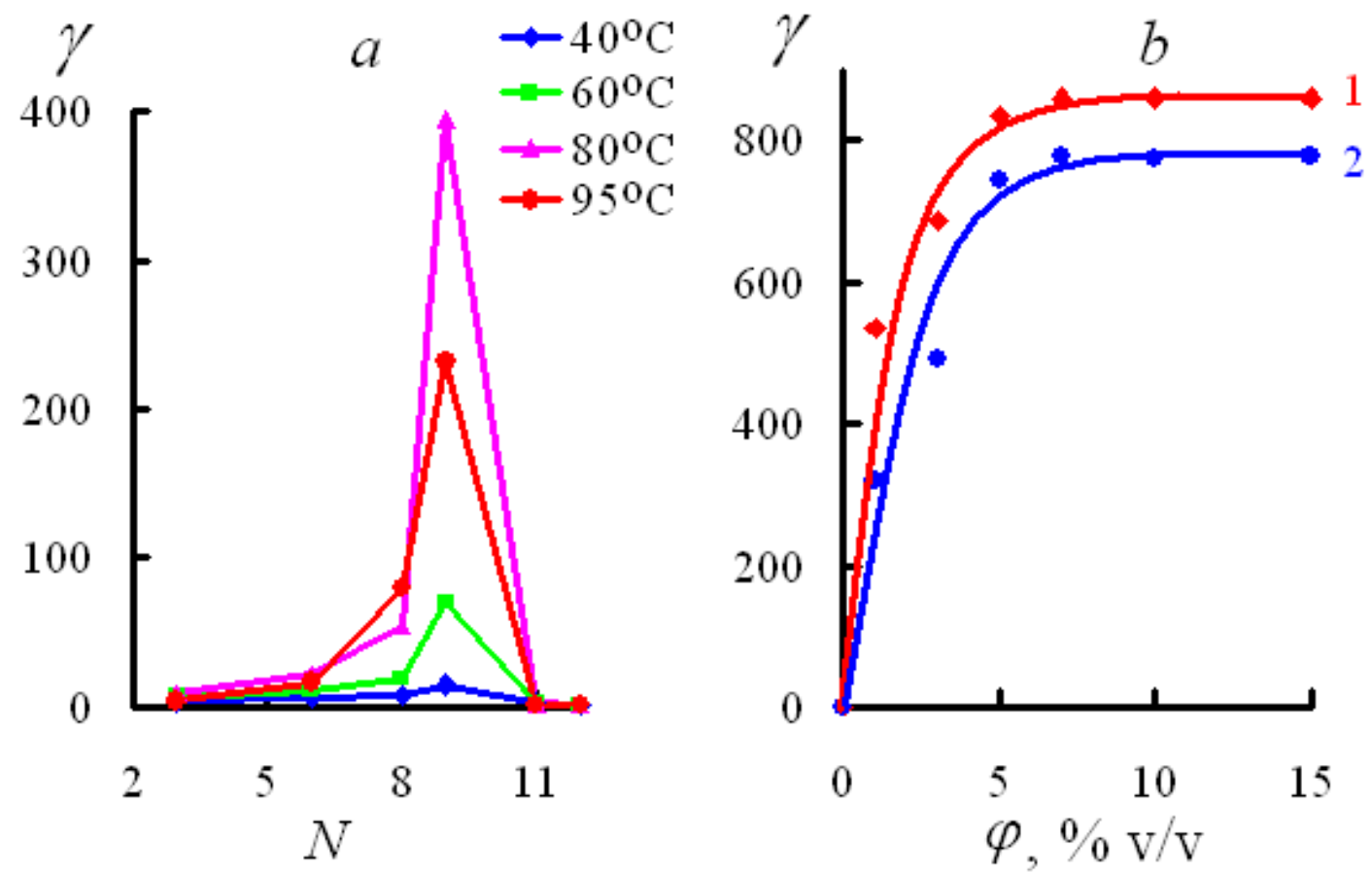

Figure 3. Variation of steel corrosion inhibition factors for Steel 20 in $5 \mathrm{M} \mathrm{HCl}$ with addition of acetylenic alcohols $(10 \mathrm{mM}) v s$. the number of carbon atoms in them $(a)$ and variation of steel corrosion inhibition factors for Steel 10 in $5 \mathrm{M} \mathrm{HCl}\left(90^{\circ} \mathrm{C}\right)$ with addition of $10 \mathrm{mM}$ dodec-1-yn-3-ol (1) and $10 \mathrm{mM}$ phenyl propargyl ether (2) vs. the volume concentration of ethanol $(b)$.

A study on the protective effect of binary formulations of CAs with nitrogen-containing compounds (urotropine condensation products -PKU and BA-6) on the corrosion of lowcarbon steel in $\mathrm{HCl}$ solutions showed (Table 3) that hex-1-yn-3-ol, optimally combined with BA-6, is most promising for the creation of HCIs [71, 72]. At $t \geq 110^{\circ} \mathrm{C}$, the protective effect of binary formulations based on hex-1-yn-3-ol can be improved significantly by adding KI. It was shown that AC-based composite CIs do not totally lose their protective effect even at $250^{\circ} \mathrm{C}$. At this temperature, the protective effect of mixed CIs does not depend on whether they contain KI. This is due to the fact that the iodide anion ceases to be adsorbed on steel at $t \geq 250^{\circ} \mathrm{C}$. The most interesting mixture comprises $1 \%$ hex-1-yn-3-ol $+1 \%$ BA- $6+0.1 \%$ KI. Its efficiency temperature maximum lies at $100^{\circ} \mathrm{C}$ and the ascending and descending branches of the curve are symmetrical with respect to the maximum (Figure 4). With an increase in pressure $(p)$, the protective effect of mixed CIs can decrease significantly. In fact, in $4 \mathrm{M} \mathrm{HCl}\left(150^{\circ} \mathrm{C}\right)$ the $k$ values of Steel 1 in the presence of $1 \% \mathrm{PA}+1 \% \mathrm{BA}-6+0.1 \% \mathrm{KI}$ are $0.41,0.75$ and $1.75 \mathrm{~kg} /\left(\mathrm{m}^{2} \cdot \mathrm{h}\right)$ at 100,300 and $700 \mathrm{~atm}$, respectively. 
Table 3.* Average and differential corrosion rates $\left(k_{\mathrm{av}}\right.$ and $\left.k_{\mathrm{dif}}, \mathrm{kg} /\left(\mathrm{m}^{2} \cdot \mathrm{h}\right)\right)$ of Steel 1 in $4 \mathrm{M} \mathrm{HCl}(p=$ $300 \mathrm{~atm})$ [71].

\begin{tabular}{|c|c|c|c|c|c|c|c|c|c|}
\hline \multirow{2}{*}{ Inhibitor } & \multirow{2}{*}{$\begin{array}{l}k_{\text {av }} \\
k_{\text {dif }}\end{array}$} & \multicolumn{8}{|c|}{ Temperature, ${ }^{\circ} \mathrm{C}$} \\
\hline & & 110 & 130 & 150 & 170 & 190 & 210 & 230 & 250 \\
\hline \multirow{2}{*}{-} & $k_{\mathrm{av}}$ & 10.15 & 14.51 & 19.00 & 21.60 & 60.00 & 40.00 & 58.53 & 47.63 \\
\hline & $k_{\text {dif }}$ & 13.80 & 26.12 & 43.47 & 63.70 & 98.12 & 52.64 & 88.66 & 79.00 \\
\hline \multirow{2}{*}{$1 \% \mathrm{PA}$} & $k_{\mathrm{av}}$ & 0.022 & 3.12 & 6.70 & - & - & - & - & - \\
\hline & $k_{\text {dif }}$ & 0.022 & 3.50 & 9.80 & - & - & - & - & - \\
\hline \multirow{2}{*}{$1 \%$ Hex-1-yn-3-ol } & $k_{\mathrm{av}}$ & 0.011 & 0.212 & 5.67 & - & - & - & - & - \\
\hline & $k_{\mathrm{dif}}$ & 0.011 & 0.212 & 7.60 & - & - & - & - & - \\
\hline \multirow{2}{*}{$1 \% \mathrm{PKU}$} & $k_{\mathrm{av}}$ & 0.226 & 0.580 & 1.94 & 6.62 & - & - & - & - \\
\hline & $k_{\text {dif }}$ & 0.226 & 0.583 & 2.03 & 9.79 & - & - & - & - \\
\hline \multirow{2}{*}{$1 \%$ BA-6 } & $k_{\mathrm{av}}$ & 0.110 & 0.360 & 4.10 & 8.80 & - & - & - & - \\
\hline & $k_{\mathrm{dif}}$ & 0.110 & 0.360 & 4.47 & 41.32 & - & - & - & - \\
\hline \multirow{2}{*}{$\begin{array}{l}1 \% \text { Hex-1-yn-3-ol } \\
+1 \% \text { PKU }\end{array}$} & $k_{\mathrm{av}}$ & 0.010 & 0.057 & 0.370 & 1.60 & 6.70 & - & - & - \\
\hline & $k_{\text {dif }}$ & 0.010 & 0.057 & 0.370 & 1.78 & 9.83 & - & - & - \\
\hline \multirow{2}{*}{$\begin{array}{c}1 \% \text { PA } \\
+1 \% \text { BA-6 }\end{array}$} & $k_{\mathrm{av}}$ & 0.018 & 0.112 & 0.800 & 3.15 & - & - & - & - \\
\hline & $k_{\mathrm{dif}}$ & 0.018 & 0.112 & 0.805 & 3.51 & - & - & - & - \\
\hline \multirow{2}{*}{$\begin{array}{c}1 \% \text { Hex-1-yn-3-ol } \\
+1 \% \text { BA-6 }\end{array}$} & $k_{\mathrm{av}}$ & 0.0096 & 0.045 & 0.244 & 0.802 & 2.20 & 5.90 & 7.90 & 8.52 \\
\hline & $k_{\text {dif }}$ & 0.0096 & 0.045 & 0.244 & 0.804 & 2.34 & 6.53 & 15.40 & 24.58 \\
\hline \multicolumn{10}{|c|}{$0.1 \% \mathrm{KI}$} \\
\hline \multirow{2}{*}{$\begin{array}{l}1 \% \text { Hex-1-yn-3-ol } \\
\quad+1 \% \text { PKU }\end{array}$} & $k_{\mathrm{av}}$ & - & 0.048 & 0.230 & 1.18 & 5.02 & - & - & - \\
\hline & $k_{\mathrm{dif}}$ & - & 0.048 & 0.230 & 1.20 & 6.30 & - & - & - \\
\hline \multirow{2}{*}{$\begin{array}{c}1 \% \text { Hex-1-yn-3-ol } \\
+1 \% \text { BA-6 }\end{array}$} & $k_{\mathrm{av}}$ & 0.0093 & 0.035 & 0.174 & 0.561 & 1.56 & 2.15 & 7.20 & 8.52 \\
\hline & $k_{\mathrm{dif}}$ & 0.0093 & 0.035 & 0.174 & 0.563 & 1.61 & 2.24 & 11.20 & 24.58 \\
\hline \multicolumn{10}{|c|}{$0.1 \% \mathrm{KI}+0.1 \% \mathrm{CrCl}_{3}$} \\
\hline $1 \%$ Hex-1-yn-3-ol & $k_{\mathrm{av}}$ & 0.0071 & 0.025 & 0.102 & 0.407 & 1.30 & 2.20 & 6.29 & - \\
\hline$+1 \%$ BA-6 & $k_{\mathrm{dif}}$ & 0.0071 & 0.025 & 0.102 & 0.472 & 1.35 & 2.30 & 8.89 & - \\
\hline
\end{tabular}

$*$ The method for calculating $k_{\mathrm{av}}$ и $k_{\mathrm{dif}}$ is presented in [1]. 


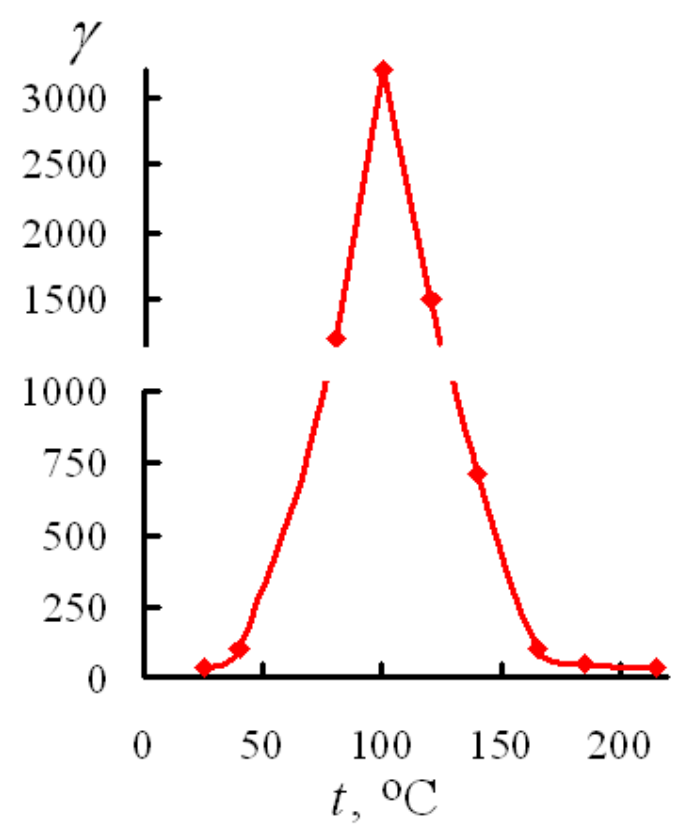

Figure 4. Variation of steel corrosion inhibition factors for Steel 1 in $15 \% \mathrm{HCl}$ with addition of $1 \%$ hex-1-yn-3-ol + 1\% BA-6 + 0.1\% KI vs. temperature.

A significant drawback of formulations based on PA and hex-1-yn-3-ol is that their protective effect in hot acid solutions decreases with time [71, 72], which largely results from chemical transformations of the ACs in the acid medium. As a result of these transformations, ACs ultimately undergo polymerization in the bulk of the acid and are removed from the corrosive medium [73]. For example, it was shown [71, 72] that in $4 \mathrm{M}$ $\mathrm{HCl}\left(170^{\circ} \mathrm{C}\right)$ inhibited by $1 \%$ hex-1-yn-3-ol $+1 \% \mathrm{BA}-6+0.1 \% \mathrm{KI}$, the value of $k_{\mathrm{av}}$ for Steel 1 in 20 -minute corrosion tests amounted to $0.561 \mathrm{~kg} /\left(\mathrm{m}^{2} \cdot \mathrm{h}\right)$. If this inhibited acid was preliminarily kept for 2 hours at $t=150$ or $170^{\circ} \mathrm{C}$, then $k_{\mathrm{av}}$ was 0.620 or $0.800 \mathrm{~kg} /\left(\mathrm{m}^{2} \cdot \mathrm{h}\right)$, respectively. For the same reason, the corrosion rate of Steel 1 strongly depends on the duration of corrosion tests. In $10,20,30$ and 60 -minute corrosion tests at $t=170^{\circ} \mathrm{C}$, the $k_{\mathrm{av}}$ values were $0.480,0.561,0.575$ and $0.660 \mathrm{~kg} /\left(\mathrm{m}^{2} \cdot \mathrm{h}\right)$, respectively.

The protective effect of organic CIs is sometimes improved by combining them with certain metal salts, such as $\mathrm{Cu}(\mathrm{II}), \mathrm{Ni}(\mathrm{II}), \mathrm{Sn}(\mathrm{II}), \mathrm{Sb}(\mathrm{III})$ and $\mathrm{Ce}(\mathrm{IV})$ [74-80]. This method of improving protection by organic CIs is hazardous for the subsequent operation of the steel structures being protected. Contacting steel structures with solutions containing metal cations capable of being reduced by metallic iron results in the liberation of these elements in metallic phase. Microgalvanic couples of dissimilar metals appearing on the steel surface can cause local corrosion. Additives such as $\mathrm{CrCl}_{3}, \mathrm{SnCl}_{2}, \mathrm{AlCl}_{3}, \mathrm{NiCl}_{2}$, and $\mathrm{CdCl}_{2}$ (Table 4) were studied as enhancers of the protective action of PA (Table 4). Among these, $\mathrm{CrCl}_{3}$ and $\mathrm{SnCl}_{2}$ provide a protective effect $[71,72]$. The same additives enhance the protective effect of hex-1-yn-3-ol itself and its binary and three-component mixtures. The effect of $\mathrm{CrCl}_{3}$ addition on the action of composite CIs is observed not only on Steel 1 but also on carbon 
steel 36G2S. In $4 \mathrm{M} \mathrm{HCl}\left(t \leq 150^{\circ} \mathrm{C}\right)$ in the presence of $1 \%$ hex-1-yn-3-ol $+1 \%$ PKU $+0.1 \%$ $\mathrm{KI}$, the $k$ value of steel $36 \mathrm{G} 2 \mathrm{~S}$ is $1.12 \mathrm{~kg} /\left(\mathrm{m}^{2} \cdot \mathrm{h}\right)$, while in the presence of $1 \%$ hex-1-yn-3$\mathrm{ol}+1 \% \mathrm{PKU}+0.1 \% \mathrm{KI}+0.1 \% \mathrm{CrCl}_{3}$, it is $0.40 \mathrm{~kg} /\left(\mathrm{m}^{2} \cdot \mathrm{h}\right)[72]$.

Table 4. Average corrosion rates $\left(k_{\mathrm{av}}, \mathrm{kg} /\left(\mathrm{m}^{2} \cdot \mathrm{h}\right)\right)$ of Steel 1 in $4 \mathrm{M} \mathrm{HCl}(p=300 \mathrm{~atm})$ [71].

\begin{tabular}{cccc}
\hline & \multicolumn{3}{c}{ Temperature, ${ }^{\circ} \mathbf{C}$} \\
\cline { 2 - 4 } Salt added & $\mathbf{1 1 0}$ & $\mathbf{1 3 0}$ & $\mathbf{1 5 0}$ \\
\hline- & 10.15 & 14.51 & 19.00 \\
\hline- & $1 \% \mathrm{PA}$ & & 6.70 \\
$0.1 \% \mathrm{SnCl}_{2}$ & 0.022 & 3.12 & 2.53 \\
$0.1 \% \mathrm{CrCl}_{3}$ & 0.011 & 0.095 & 5.72 \\
$0.1 \% \mathrm{AlCl}_{3}$ & 0.017 & - & - \\
$0.1 \% \mathrm{NiCl}_{2}$ & 0.022 & - & - \\
$0.1 \% \mathrm{CdCl}_{2}$ & 0.021 & - & - \\
\hline & 0.022 & - & 5.67 \\
\hline & $1 \% \mathrm{Hex}-1-\mathrm{yn}-3-\mathrm{ol}$ & - & 4.12 \\
\hline
\end{tabular}

$1 \%$ Hex-1-yn-3-ol + 1\% BA-6

\begin{tabular}{ccccc}
\hline- & - & - & 0.244 \\
$0.1 \% \mathrm{CrCl}_{3}$ & - & - & - & 0.191 \\
$0.4 \% \mathrm{CrCl}_{3}$ & $1 \% \mathrm{Hex}-1-\mathrm{yn}-3-\mathrm{ol}+1 \% \mathrm{BA}-6+0.1 \% \mathrm{KI}$ & 0.170 \\
\hline & - & - & - & 0.174 \\
$0.1 \% \mathrm{CrCl}_{3}$ & - & - & 0.102 \\
$0.2 \% \mathrm{CrCl}_{3}$ & - & - & 0.164 \\
$0.3 \% \mathrm{CrCl}_{3}$ & - & - & 0.168 \\
$0.4 \% \mathrm{CrCl}_{3}$ & - & - & 0.182 \\
$0.1 \% \mathrm{SnCl}_{2}$ & & - & 0.147 \\
\hline
\end{tabular}




\begin{tabular}{|c|c|c|c|}
\hline \multirow{2}{*}{ Salt added } & \multicolumn{3}{|c|}{ Temperature, ${ }^{\circ} \mathrm{C}$} \\
\hline & 110 & 130 & 150 \\
\hline \multicolumn{4}{|c|}{$1 \%$ Hex-1-yn-3-ol + 1\% PKU } \\
\hline- & - & - & 0.370 \\
\hline $0.1 \% \mathrm{CrCl}_{3}$ & - & - & 0.290 \\
\hline $0.2 \% \mathrm{CrCl}_{3}$ & - & - & 0.230 \\
\hline \multicolumn{4}{|c|}{$1 \%$ Hex-1-yn-3-ol + 1\% PKU + 0.1\% KI } \\
\hline- & - & - & 0.152 \\
\hline $0.1 \% \mathrm{CrCl}_{3}$ & - & - & 0.102 \\
\hline $0.4 \% \mathrm{CrCl}_{3}$ & - & - & 0.074 \\
\hline
\end{tabular}

The results reported in $[71,72]$ are interesting because they contain detailed practical information on the corrosion of steels in inhibited $\mathrm{HCl}$ solutions at temperatures up to $250^{\circ} \mathrm{C}$. These studies showed not only the advantages of the CIs studied but also their drawbacks that can be encountered in industrial use. The practically important operational properties of inhibited acid solutions, namely, the temperature range of their application and the thermal instability of CIs over time, can only be determined by performing high-temperature studies.

The approaches to the creation of HCIs discussed above were actually implemented in the development of some patented inhibitor mixtures. Keeney and Johnson [81] suggested formulations comprising acetylenic alcohols, nitrogen-containing compounds and $\mathrm{CuI}$ that are efficient $\mathrm{HCIs}$ of steels (20-25000 ppm) in $\mathrm{HCl}, \mathrm{H}_{2} \mathrm{SO}_{4}, \mathrm{HF}, \mathrm{H}_{3} \mathrm{CCOOH}$ and their mixtures at $t \leq 230^{\circ} \mathrm{C}$. Instead of acetylenic alcohols, mercapto acetylenic derivatives with the following general formula can be used:

$$
\mathrm{HC} \equiv \mathrm{C}-\mathrm{R}-\mathrm{S}-\mathrm{R}-\mathrm{C} \equiv \mathrm{CH}
$$

The nitrogen-containing compounds that are suggested for use include primary, secondary and tertiary amines containing $\mathrm{C}_{2}-\mathrm{C}_{6}$ hydrocarbon radicals, as well as pyridine derivatives. Walker [82] described formulations for protecting $\mathrm{N} 80$ steel in solutions of $\mathrm{HCl}$, $\mathrm{HCl}+\mathrm{HF}, \mathrm{H}_{2} \mathrm{SO}_{4}, \mathrm{H}_{3} \mathrm{CCOOH}$ and $\mathrm{HCOOH}$ at $t \leq 260^{\circ} \mathrm{C}$. The formulations contain an acetylenic alcohol (5-35\%), a quaternary ammonium salt, an aromatic hydrocarbon, and a soluble antimony compound.

Unsaturated carbonyl compounds constitute the second group of compounds that are used to create mixed HCIs [83]. While the earliest patent [84] suggested to use individual unsaturated aromatic aldehydes as $\mathrm{CIs}$ to protect carbon steel in dilute $\mathrm{HCl}\left(t \leq 100^{\circ} \mathrm{C}\right)$, later developments suggest to use unsaturated carbonyl compounds in formulations [85]. Nitrogen-containing compounds are recommended for the protection of steels in solutions of $\mathrm{HCl}, \mathrm{H}_{2} \mathrm{SO}_{4}, \mathrm{H}_{3} \mathrm{PO}_{4}, \mathrm{H}_{3} \mathrm{CCOOH}, \mathrm{HCOOH}$, citric acid and mixtures thereof $\left(t \leq 150^{\circ} \mathrm{C}\right)$ 
containing chelating agents (ethylenediaminetetraacetic and $N$-(2-hydroxyethyl)ethylenediamine- $N, N^{\prime}, N^{\prime}$-triacetic acids). The patent [86] reports data on the protection of $\mathrm{N} 80$ steel in $15-28 \% \mathrm{HCl}\left(t=150^{\circ} \mathrm{C}\right)$ containing additives of $\mathrm{KI}(1-2 \%)$ and $\mathrm{HCOOH}$ by mixtures of phenylalkenylketones with alkyl- or alkylarylquinolinium salts. A mixture comprising various acetylenic alcohols, phenyl vinyl ketone, KI and $\mathrm{HCOOH}$ was recommended for the protection of carbon steels N80, J55 and chromium stainless steel L80 in $\mathrm{HCl}$ solutions at $t \leq 150^{\circ} \mathrm{C}$ [87]. Jasinski and Frenier [88] recommend to protect steels containing more than $9 \% \mathrm{Cr}$ in $15 \% \mathrm{HCl}$ and its mixtures with $\mathrm{HF}\left(t=120-250^{\circ} \mathrm{C}\right)$ using formulations of phenylalkenylketones or substituted cinnamic aldehydes with derivatives of nitrogen-containing heterocycles (alkylpyridinium and alkylquinolinium salts). In order to enhance the protective action of these mixtures, the effect of $\mathrm{Bi}$ (III) and $\mathrm{Sb}$ (III) compounds, as well as $\mathrm{CuCl}$ soluble in acidic media, on the above mixtures was studied. Furthermore, the protective effect of the mixtures was enhanced by addition of $\mathrm{KI}$ or $\mathrm{HCOOH}$.

Vorderbruggen and Williams [89] patented inhibited acid formulations to stimulate the release of water from water-bearing formations and hydrocarbons from oil formations at temperatures up to $120^{\circ} \mathrm{C}$. The formulations may contain $\mathrm{HCl}, \mathrm{HF}, \mathrm{H}_{3} \mathrm{CCOOH}, \mathrm{HCOOH}$, sulfamic acid or mixtures thereof as the acid. The CI should contain cynnamaldehyde and a sulfur-containing organic compound. This CI mixture can be modified with potassium iodide, $\mathrm{HCOOH}$, or a mixture thereof. Moreover, pyridine or quinoline derivatives or quaternary ammonium salts may be incorporated in the CI additionally.

A later patent [90] deals with the development of acid formulations at temperatures up to $175^{\circ} \mathrm{C}$. The authors believe that the previously developed enhancers of HCI protective action (KI, $\mathrm{HCOOH}$, antimony compounds, etc.) have technologically unacceptable drawbacks: their effect is time-limited and they do not work in concentrated acids; they do not provide the necessary temperature range where metals are protected, and the compounds themselves are environmentally hazardous. However, they find a strange solution to the problem by replacing them with no less toxic organic phosphine derivatives. In general, the solutions given in the patent have complex compositions. It is intended to use inorganic acids $(\mathrm{HCl}$ and $\mathrm{HF}$ ), a wide range of organic acids and their mixtures in these solutions. ACs or cinnamaldehyde derivatives serve as inhibiting components. It is intended to enhance their protective effect by organic derivatives of phosphine and carbonyl compounds that include an active $\alpha$-hydrogen atom in their structures. Additionally, the presence of technological additives, such as surfactants, solvents, scaling inhibitors, biocides, foaming agents, etc., is allowed in the solution.

A formulation is suggested that is claimed to contain no $\mathrm{HCOOH}$ [91]. It includes a mineral acid, a surfactant, a gelling agent and a CI, and can be used at temperatures up to $107^{\circ} \mathrm{C}$. The $\mathrm{CI}$ is a mixture of aldehydes that must contain an $\alpha, \beta$-unsaturated aldehyde or an alkenylphenone. $\mathrm{CuI}, \mathrm{CuCl}$, or a mixture thereof can be used as the $\mathrm{CI}$ enhancer.

Complex mixed CIs based on unsaturated carbonyl compounds and azomethines were considered in a number of works [40, 92-96], but as a rule, no data on their effect at 
$t>100^{\circ} \mathrm{C}$ is provided. An attempt to create HCIs using formaldehyde (a saturated aldehyde) as the basis [97] failed, which confirms the uniqueness of unsaturated carbonyl compounds in this respect.

As noted above, individual UCs are not quite suitable for steel protection in $\mathrm{H}_{2} \mathrm{SO}_{4}$ solutions, but their mixtures with halide anions are efficient in this medium [98, 99]. The efficiency of halide anions increases in the series $\mathrm{Cl}^{-}<\mathrm{Br}^{-}<\mathrm{I}^{-}$. In $15 \% \mathrm{H}_{2} \mathrm{SO}_{4}\left(107^{\circ} \mathrm{C}\right)$ on Steel $10\left(k_{0}=1.75 \mathrm{~kg} /\left(\mathrm{m}^{2} \cdot \mathrm{h}\right)\right)$, the addition of $0.4 \%$ hex-1-yn-3-ol $+5 \%$ ethanol provides $\gamma=1.5$, while the addition of $0.4 \%$ hex-1-in-3-ol $+5 \%$ ethanol $+0.1 \mathrm{M} \mathrm{KCl}$ provides $\gamma=1300$. Phenol propargyl ether is somewhat abnormal in this respect. For $0.13 \%$ phenol propargyl ether $+5 \%$ ethanol, $\gamma=230$. Its formulation with $0.1 \mathrm{M} \mathrm{KCl}$ provides $\gamma=930$, and with $0.1 \mathrm{M}$ $\mathrm{KI}, \gamma=2450$ [98]. Rhodanide anions and sulfur-containing organic compounds are promising additives to UCs for the protection of steels in $\mathrm{H}_{2} \mathrm{SO}_{4}$ solutions [34, 100], although the studies of these mixtures are limited to $t=60^{\circ} \mathrm{C}$.

The use of individual UCs is not promising in HCI development, but it is justified in complex formulations. The protective effect of UCs can be improved by creating their formulations with nitrogen-containing organic compounds, organic solvents, compounds of some metals ( $\mathrm{Cr}(\mathrm{III}), \mathrm{Sb}(\mathrm{III}), \mathrm{Bi}(\mathrm{III}), \mathrm{Cu}(\mathrm{I})$ ) and metal iodides. As a rule, multicomponent mixtures are more efficient in the creation of HCIs. Sometimes a single component can perform a number of functions. For example, alkylpyridinium chlorides are simultaneously nitrogen-containing organic additives capable of slowing down the corrosion of steel by themselves, and surfactants that improve the distribution of hardly soluble UCs in an acid. The presence of $\mathrm{CuI}$ in a corrosive medium supplies iodide anions and $\mathrm{Cu}(\mathrm{I})$ cations into the acid solution.

The development of industrial formulations of ready-made acid solutions is more promising. It has to be understood that special-purpose additives (gelling agents, surfactants, solvents, scale inhibitors, biocides, foaming agents, etc.) can also improve the protective effect of CIs added to a solution. In contrast, some CI components can simultaneously serve as special-purpose components.

Let us discuss the technological drawbacks of composite CIs based on UCs. Unfortunately, only some of them are recommended for the protection of steels at temperatures up to $250^{\circ} \mathrm{C}$, although this temperature is largely determined by the requirements of the oil industry [1]. They are unstable in time in hot solutions, i.e., their protective effect decreases with time and with an increase in pressure. The components of mixed HCIs, namely, UCs themselves, especially ACs; pyridine and quinoline derivatives; $\mathrm{Cr}(\mathrm{III}), \mathrm{Sb}$ (III) and $\mathrm{Bi}(\mathrm{III})$ compounds; $\mathrm{HCOOH}$; and organic derivatives of phosphine are quite toxic. Nuclear power plants are potentially fire- and explosion-dangerous in operation. Alkali metal iodides that always improve the effect of HCIs are expensive, which certainly limits their use. 


\section{Mechanism of the protective action of unsaturated organic compounds}

The mechanism of the protective action of organic compounds on the corrosion of steels in acids is based on their adsorption on a metal surface. Upon adsorption, a monomolecular or polymolecular protective layer is formed on a steel surface. The layer of an organic inhibitor adsorbed on a metal surface prevents the cathodic and anodic reactions and thus slows down the corrosion. The efficiency of metal protection with polymolecular CI layers is higher than in the case of monolayers. To a considerable extent, a decisive role in slowing down the corrosion of steel is played by the strength of bonding between the molecules in the adsorbed CI layer and the metal surface, and in the case of a polymolecular protective film, between the molecules of the organic CI layers inside it. The most efficient protection can be expected from a CI if its molecules are bound by chemical bonds with the metal surface and with each other within the protective layer. Our long-term experience in the study of HCIs shows that only such CIs are capable of providing the necessary metal protection at elevated temperatures.

The adsorption of UCs on steel surfaces from acid solutions is determined by the presence of unsaturated bonds between their carbon atoms. In fact, a quantum-mechanical analysis of the possible adsorption scenarios of PA, i.e., the simplest acetylenic alcohol, on a steel surface indicates that it interacts with the steel surface through the $\mathrm{C} \equiv \mathrm{C}$ moiety [101]. In parallel, it was shown by the chronopotentiometric method that PA adsorption occurred exclusively on the surface of steel coated with adsorbed hydrogen. Though the literature available to us contains no results on the estimation of UC adsorption on steel from acid solutions by direct methods, there is a lot of data on the determination of the free energy of adsorption of UCs $\left(-\Delta G_{\text {ads }}\right)$ obtained in a less strict way, viz., by processing the results of measuring the mass loss of steel samples in inhibited acid solutions. There is a considerable amount of data (Table 5) where the free energy of adsorption $\left(-\Delta G_{\text {ads }}^{0}\right)$ approaches or exceeds $40 \mathrm{~kJ} / \mathrm{mol}$, which allows one to make the assumption that the interaction of UCs with the surface of the metals being protected is of predominantly chemical or purely chemical nature. In the case of steel protection in acid solutions with UCs, it is precisely this interaction that provides a strong bond of the polymolecular protective layer formed with the metal substrate.

In the protective layer formed by UCs on the steel surface, an inhibitor molecule is bound chemically. Within the protective layer, oligomerization of the UC occurs first, which ultimately leads to the formation of a three-dimensional protective polymer film. The polymerization of ACs is confirmed by IR spectroscopy data [107-110]. The IR spectra of compounds present in the protective film contain no signal of the $\mathrm{C} \equiv \mathrm{C}$ bond that is characteristic of the starting compounds. The thickness of the protective films formed is 2$20 \mathrm{~nm}$ [107]. Similar results are given by Raman spectroscopy for the protection of PS steel in an $\mathrm{HCl}$ solution [111]. The results of IR spectroscopy also indicate that chemical transformations occur on steel surfaces in $\mathrm{HCl}$ solutions of unsaturated aldehydes and 
ketones [35, 112]. The products of the conversion of acetylenic alcohols [113, 114] and their halogenated derivatives [12] in a corrosive medium were identified and the simplest formulas of these compounds were determined. Moreover, in general, one should be critical of data on the identification of UC conversion products, since some of these products may result from their reactions in the bulk of the acid rather than on the metal surface.

Table 5. Free adsorption energies of unsaturated compounds on steels from acid media.

\begin{tabular}{|c|c|c|c|c|c|}
\hline No. & Inhibitor & System & $\begin{array}{c}\text { Standard } \\
\text { adsorption free } \\
\text { energy } \\
\left(-\Delta G_{\text {ads }}\right) \\
\mathbf{k J} / \mathbf{m o l}\end{array}$ & $\begin{array}{c}\text { Adsorption } \\
\text { isotherm }\end{array}$ & Ref. \\
\hline \multicolumn{6}{|c|}{ Acetylene compounds } \\
\hline 1 & PA & $\begin{array}{c}15 \% \mathrm{HCl} \\
\left(105^{\circ} \mathrm{C}\right), \text { mild } \\
\text { steel }\end{array}$ & 47.2 & $\begin{array}{c}\text { Temkin } \\
\text { isotherm }\end{array}$ & [18] \\
\hline 2 & Oct-1-yn-3-o1 & $\begin{array}{l}4.5 \mathrm{M} \mathrm{HCl} \\
\left(65^{\circ} \mathrm{C}\right), \mathrm{J} 55\end{array}$ & 50.2 & $\begin{array}{l}\text { Langmuir } \\
\text { isotherm }\end{array}$ & {$[102]$} \\
\hline 3 & $\begin{array}{l}p \text {-(9-[2-Methyl-2-(2-popyn-1- } \\
\text { yl)isoxazolidinium-5- } \\
\text { yl]nonyloxy)cinnamaldehyde } \\
\text { chloride }\end{array}$ & $\begin{array}{l}4.5 \mathrm{M} \mathrm{HCl} \\
\left(60^{\circ} \mathrm{C}\right), \text { mild } \\
\text { steel }\end{array}$ & 45.4 & $\begin{array}{l}\text { Langmuir } \\
\text { isotherm }\end{array}$ & [28] \\
\hline \multicolumn{6}{|c|}{ Aldehydes and ketones } \\
\hline 4 & $\begin{array}{l}\text { Dicinnamylidene acetone, } \\
\text { disalicylidene acetone, } \\
\text { divanillidene acetone }\end{array}$ & $\begin{array}{c}15 \% \mathrm{HCl} \\
\left(105^{\circ} \mathrm{C}\right), \mathrm{N} 80\end{array}$ & $\begin{array}{l}41.8 \\
46.0 \\
29.3\end{array}$ & $\begin{array}{c}\text { Temkin } \\
\text { isotherm }\end{array}$ & [36] \\
\hline 5 & $\begin{array}{c}\text { 3-(4-(Dimethylamino)phenyl)- } \\
\text { 1-(4- hydroxyphenyl)prop-2-en- } \\
\text { 1-one, } \\
\text { 3-(3-Hydroxyphenyl)-1-(4- } \\
\text { hydroxyphenyl)prop-2-en-1- } \\
\text { one, } \\
\text { 1-(4-Hydroxyphenyl)-3- } \\
\text { phenylprop-2-en-1-one, } \\
\text { 1-(4-Hydroxyphenyl)-3-(4- } \\
\text { nitrophenyl)prop-2-en-1-one }\end{array}$ & $\begin{array}{c}1 \mathrm{M} \mathrm{HCl}\left(25^{\circ} \mathrm{C}\right), \\
\text { carbon steel }\end{array}$ & $\begin{array}{l}43.3 \\
42.5 \\
41.3 \\
40.0 \\
\\
45.4 \\
43.3 \\
40.9 \\
39.1\end{array}$ & $\begin{array}{l}\text { Langmuir } \\
\text { isotherm }\end{array}$ & {$[103]$} \\
\hline 6 & $\begin{array}{l}\text { Benzoyl Allyl Alcohol (with the } \\
\text { surfactant } N \text {-dodecylpyridinium } \\
\text { bromide) }\end{array}$ & $\begin{array}{l}16-28 \% \mathrm{HCl} \\
\left(65.5^{\circ} \mathrm{C}\right), \mathrm{J} 55\end{array}$ & $44.0-60.9$ & $\begin{array}{l}\text { Langmuir } \\
\text { isotherm }\end{array}$ & [40] \\
\hline
\end{tabular}




\begin{tabular}{|c|c|c|c|c|c|}
\hline No. & Inhibitor & System & $\begin{array}{c}\text { Standard } \\
\text { adsorption free } \\
\text { energy } \\
\left(-\Delta G_{\text {ads }}\right) \\
\mathbf{k J} / \mathbf{m o l}\end{array}$ & $\begin{array}{l}\text { Adsorption } \\
\text { isotherm }\end{array}$ & Ref. \\
\hline \multicolumn{6}{|c|}{ Azomethines } \\
\hline 7 & $\begin{array}{l}\text { 1,4-Dicinnamylidene } \\
\text { aminophenylene }\end{array}$ & $\begin{array}{c}1 \mathrm{M} \mathrm{HCl} \\
\left(35-65^{\circ} \mathrm{C}\right) \\
\text { mild steel }\end{array}$ & $39.3-41.1$ & $\begin{array}{l}\text { Temkin } \\
\text { isotherm }\end{array}$ & {$[104]$} \\
\hline 8 & $\begin{array}{c}\text { (E)-N-((E)-3-Phenylallylidene)- } \\
\text { 2-(phenylthio)aniline }\end{array}$ & $\begin{array}{c}1 \mathrm{M} \mathrm{HCl} \\
\left(30-60^{\circ} \mathrm{C}\right) \\
\text { carbon steel }\end{array}$ & $37.8-42.9$ & $\begin{array}{l}\text { Langmuir } \\
\text { isotherm }\end{array}$ & {$[105]$} \\
\hline 9 & $\begin{array}{l}\text { 2-(2 Hydroxyphenyl)-2,5-diaza- } \\
\text { 4,6-dimethyl-8-hydroxy-1,5,7- } \\
\text { nonatriene }\end{array}$ & $\begin{array}{l}1 \mathrm{M} \mathrm{HCl}\left(27^{\circ} \mathrm{C}\right) \\
\text { mild steel }\end{array}$ & 36.1 & $\begin{array}{l}\text { Langmuir } \\
\text { isotherm }\end{array}$ & {$[106]$} \\
\hline 10 & $\begin{array}{l}\text { 1-Cinnamylidene-3- } \\
\text { thiocarbohydrazide, } \\
\text { 1,1'-Dicinnamylidene-3- } \\
\text { thiocarbohydrazide }\end{array}$ & $\begin{array}{c}15 \% \mathrm{HCl} \\
\left(30-110^{\circ} \mathrm{C}\right) \\
\text { carbon steel }\end{array}$ & $\begin{array}{l}32.9-41.4 \\
35.6-44.7\end{array}$ & $\begin{array}{l}\text { Temkin } \\
\text { isotherm }\end{array}$ & [37] \\
\hline
\end{tabular}

More detailed information on the conversion of UCs on steel surfaces in acidic media can be obtained by means of chromato-mass spectrometry $[115,116]$. In fact, products of $\mathrm{CA}$ conversion on steel surface in $\mathrm{HCl}$ solutions were identified $[34,112,117]$. It was shown that the protective film formed contains, along with CA, ethanol and methanol used as solvents for introducing the poorly soluble unsaturated aldehyde [34,117]. This result is extremely important for understanding the role of organic solvents added to the corrosive media for increasing the solubility of UCs. The role of organic solvents is more complex: they not only contribute to the uniform distribution of a poorly soluble UC in a corrosive environment but also participate in the formation of a protective film by the CI. Unlike CA, $\alpha$-amyl-CA in which the $\mathrm{C}=\mathrm{C}$ bond is shielded by substituents does not undergo deep chemical conversion in a corrosive medium and, as a result, fails to provide efficient steel protection in $\mathrm{HCl}$ solutions [34].

Protective films of CIs formed by acetylenic compounds [22, 118-124], unsaturated aldehydes and ketones [125-128] on steel surfaces slow down both the cathodic and anodic reactions on steels in acid solutions, which ultimately determines the efficient inhibition of metal corrosion. The inhibition of the electrode reactions on steel by UCs also persists at temperatures close to $100^{\circ} \mathrm{C}[124,126]$. The inhibition of electrode reactions increases with time and with increasing $t$ [129]. 
The formation of protective films by UCs on steel surfaces is accompanied by a decrease in the double electric layer capacitance $\left(C_{\mathrm{dl}}\right)$ on steel and an increase in the polarization resistance $[22,130,131]$. The formation of protective films from UCs on metal surfaces with time is confirmed by a decrease in $C_{\mathrm{dl}}$ that is also stretched in time. The protective CI films formed by UCs on steel favor the retention of a low $C_{\mathrm{dl}}$ on the metal in a wide range of potentials.

The reasons for the decrease in the protective effect of HCIs, including unsaturated ones, with increasing pressure in a corrosion system were determined using a set of electrochemical studies (measuring the ohmic resistance of a cell, measuring the differential capacitance and imaginary impedance, voltammetry). The decrease in the protective effect of CIs is attributed to the competitive adsorption of organic compounds and evolved hydrogen on a steel surface. The higher the pressure in the corrosion system, the more strongly hydrogen displaces a CI from the metal surface [71, 132, 133].

The correlation of the physicochemical parameters of UC molecules with their protective effect in the corrosion of steel in hydrochloric acid was considered in [134] with CA derivatives as an example. Quantum-mechanical calculation methods are in demand for explaining the effect of the UC structure on their protective effect and determining the nature of the bond of these substances with metal surfaces [135-137].

Studies on the effect of unsaturated compounds on the kinetics of electrode processes show that their ability to form protective polymer films is a necessary but insufficient condition for efficiency. Many acetylenic [10,11], aldehyde [34] and azomethine [138] inhibitors are liable to electrochemical hydrogenation on iron in acid solutions. The process can occur so readily that some of them completely lose inhibiting action. In particular, PA in hydrochloric acid solutions efficiently inhibits electrode reactions on iron (the adsorbed chloride ion hinders the hydrogenation of the unsaturated alcohol). The metal surface is coated by a protective polymeric film, as follows from an increase in the Tafel slopes of polarization curves $[119,120]$. The situation changes for iron corrosion in solutions of oxygen-containing acids (perchloric, sulfuric and phosphoric) whose anions are more hydrophilic than the chloride ion. The reduction of PA on iron surface facilitates the cathodic process; therewith, the corrosion potential increases up to the pitting potential. This leads not only to a drop in the inhibitor efficiency but also to corrosion localization. Propargyl chloride is less prone to hydrogenation than PA and polymerizes more readily, which provides for its efficiency in $\mathrm{HCl}$ and oxygen-containing acids [10]. It is hard to escape the conclusion that hydrogenation of unsaturated compounds is adverse for the inhibition of acid corrosion. It is enough to find an unsaturated compound stable to hydrogenation, and it will equally well inhibit corrosion in all acids. However, the inclination of unsaturated compounds to hydrogenation is directly related to their polymerization ability. The compounds that are not susceptible to hydrogenation are not polymerized on iron. These are CIs acting by the adsorption mechanism and having low protective effect in all acids. But2-yne-1,4-diol is an example of such CIs. It weakly inhibits the electrode processes on iron 
in $\mathrm{H}_{2} \mathrm{SO}_{4}$ and $\mathrm{HCl}$ and practically does not change the Tafel slopes of polarization curves; no polymeric film is formed on iron [131]. Hence, in solutions of oxygen-containing acids, only those unsaturated compounds can be efficient for which the polymerization process predominates over hydrogenation. Moreover, a CI must be polymerized on the metal rather than in the acid bulk.

The key point in elucidation of the mechanism of action of unsaturated compounds is the relationship between hydrogenation and polymerization of such compounds [5]. The compounds that are not inclined to hydrogenation do not form protective inhibitor films. Unsaturated compounds prone to reduction can undergo the following transformations:

1) cathodic reduction accelerating the cathodic reaction and causing inhibitor consumption;

2) polymerization in solution bulk removing the inhibitor from the corrosion medium;

3 ) formation of a protective polymeric film on the metal that is strongly bound to the steel surface. It is formed by generation of complexes between the surface metal atoms and molecules of the unsaturated compound and changes its structure in the course of time.

Considering the possible transformations, unsaturated CIs can be divided into five groups [5].

1. Unsaturated compounds that are not polymerized on iron. The mechanism of action of such CIs is by adsorption; their inhibiting action is not very high and does not depend on the acid anionic composition. But-2-yne-1,4-diol is an example.

2. Unsaturated compounds that are prone to hydrogenation and are not polymerized are represented by compounds with one double bond. Upon reduction, such CIs form saturated products and are not prone to further chemical transformations. The representatives include allyl alcohol and allyl chloride.

3. Unsaturated compounds that are prone to hydrogenation and are polymerized. This group includes compounds containing a triple bond or conjugated double bonds. These compounds are efficient in $\mathrm{HCl}$ and can be characterized by high protective action at elevated temperatures. In solutions of acids with hydrophilic anions, they are not efficient and can promote corrosion. The representatives include PA, hex-1-yn-3-ol, unsaturated azomethines and $\alpha, \beta$-unsaturated aldehydes.

4. Unsaturated compounds that are polymerized but hardly undergo hydrogenation. This group consists of acetylenic CIs whose molecules contain a hydrophobic moiety. They are efficient in all acids at elevated temperatures. The representatives include propargyl chloride and dipropargyl thioether.

5. Unsaturated compounds that are polymerized in the acid bulk. These are highly reactive compounds whose chemical transformations are catalyzed by acids; they exhibit low protective action in all acids. Dimethylethynylmethanol is an example.

Thus, the high efficiency of UC-based mixtures in the inhibition of steel corrosion in acid solutions at elevated temperatures is largely determined by the uniqueness of the mechanism of their protective action that is associated with their ability to form a strongly 
bound protective polymer layer on the metal surface. Various inhibitive additives favor the formation of these protective layers on steel surfaces at elevated temperatures. The mechanisms of action of many of these additives are not discussed or remain at hypothetical level in the majority of studies. In fact, the enhancing effect of metal cations on the protective effect of ACs is attributed to their ability to catalyze the polymerization of organic CI molecules, but it was not confirmed experimentally [71]. The mechanism of action of multicomponent CIs, in contrast to their components, is difficult to study experimentally, especially at high temperatures. It is possible that in the future this issue will be clarified using advanced research methods. Thus, the use of chromato-mass spectrometry made it possible to gain a considerable understanding of the role of organic solvents in slowing down the corrosion by UCs [34].

\section{Conclusions}

The literature and patent data on the protection of steels with UCs (AC, aldehydes, ketones and azomethines) in acid solutions at temperatures up to $250^{\circ} \mathrm{C}$ are generalized. Despite the significant differences in the structure of these compounds, there are a number of regularities that unite them by the mechanism of protective action that stems from the presence of unsaturated bonds in these compounds. In individual form, these compounds rarely effectively protect steel at $t>100^{\circ} \mathrm{C}$. However, the creation of multicomponent mixed CIs based on them allows one, in some cases, to expand their protective effect to $t=250^{\circ} \mathrm{C}$. The possibility of protecting steels at these high temperatures is a consequence of the unique inhibition mechanism of UCs that results from their ability to be chemisorbed on a metal surface and undergo deep chemical conversion to form a protective polymer film. Scientific sources mainly provide data on the protection of steels in high-temperature $\mathrm{HCl}$ solutions. It is only in patents that the possibility of their use in other inorganic and organic acids is indicated, which suggests that some limitations exist on their efficient application in these environments.

Unfortunately, the use of HCIs based on UCs involves a number of technology difficulties and hazards. The high reactivity that ensures the formation of a protective polymer film on a metal also predetermines their most important drawbacks, namely, instability of CIs in hot corrosive media in the course of time and polymerization in the acid bulk, which removes a CI from the corrosive environment and results in coking. Moreover, the UCs themselves and additives used with them are toxic compounds, which significantly limits their application prospects.

Despite the industrial use of HCIs based on UCs for the protection of steel structures in $\mathrm{HCl}$ solutions, there is an alternative approach to the development of CIs based on thermostable nitrogen-containing organic heterocycles that are free from the above drawbacks in many respects. The final part of our review will deal with the HCIs based on nitrogen-containing heterocycles, the mechanism of their protective action, and the prospects of their industrial applications. 


\section{Acknowledgements}

The study was carried out within the framework of the Program of Basic Scientific Research of the State Academies of Sciences for 2013-2020, subject "Development of the fundamental scientific basis of the protective effect of inhibitors of metal corrosion in gas and condensed media, nanocomposites, paintwork and conversion coatings" (state registration number AAAA-A18-118121090043-0).

\section{References}

1. Ya.G. Avdeev and Yu.I. Kuznetsov, Inhibitory protection of steels from hightemperature corrosion in acid solutions. A review. Part 1., Int. J. Corros. Scale Inhib., 2020, 9, no. 2, 394-426. doi: 10.17675/2305-6894-2020-9-2-2

2. S.A. Balezin, K voprosu o mekhanizme deistviya ingibitorov korrozii metallov (On the mechanism of action of metal corrosion inhibitors), in Ingibitory korrozii metallov (Metal corrosion inhibitors), MGPI im. V.I. Lenina, Moscow, 1962, Issue 2, 3-12 (in Russian).

3. S.A. Balezin, F.K. Kurbanov and N.I. Podobaev, Issledovanie zashchitnogo deistviya ingibitorov korrozii stali $\mathrm{v}$ solyanoi kislote $\mathrm{v}$ zavisimosti ot temperatury, davleniya $\mathrm{i}$ kontsentratsii kisloty (Investigation of the protective effect of steel corrosion inhibitors in hydrochloric acid depending on temperature, pressure and acid concentration), Zashch. Met. (Protection of metals), 1965, 1, no. 3, 337-340 (in Russian).

4. N.I. Podobaev and Ya.G. Avdeev, A Review of Acetylene Compounds as Inhibitors of Acid Corrosion of Iron, Prot. Met., 2004, 40, no 1, 7-13. doi: 10.1023/B:PROM.0000013105.48781.86

5. Ya.G. Avdeev and Yu.I. Kuznetsov, Physicochemical aspects of inhibition of acid corrosion of metals by unsaturated organic compounds, Russ. Chem. Rev., 2012, 81, no. 12, 1133-1145. doi: 10.1070/RC2012v081n12ABEH004292

6. Ya.G. Avdeev, Protection of Steel in Solutions of Mineral Acids Using $\alpha, \beta$-Unsaturated Aldehydes, Ketones, and Azomethines, Prot. Met. Phys. Chem. Surf., 2015, 51, no. 7, 1140-1148. doi: 10.1134/S2070205115070023

7. S.A. Balezin, N.I. Podobaev, A.G. Voskresensky and V.V. Vasiliev, O mekhanizme zashchitnogo deistviya atsetilenovykh soedinenii pri rastvorenii stali v solyanoi kislote (On the mechanism of the protective action of acetylene compounds upon dissolution of steel in hydrochloric acid), Trudy tret'yego mezhdunarodnogo kongressa po korrozii metallov (Proceedings of the Third International Congress on Metal Corrosion), Mir, Moscow, 1968, 2, 7-18 (in Russian).

8. G.L. Foster, B.D. Oakes and C.H. Kucera, Acetylenic Corrosion Inhibitors, Ind. Eng. Chem., 1959, 51, 7, 825-828. doi: 10.1021/ie50595a027 
9. N.I. Podobayev, A.G. Voskresenskiy and G.F. Semikolenov, Izuchenie v kachestve ingibitorov korrozii nekotorykh atsetilenovykh soedinenio (Study of some acetylenic compounds as corrosion inhibitors), Ingib. Korroz. Met. (Metal corrosion inhibitors), ed. S.A. Balezin, Publishing House "Sudostroenie", Moscow, 1965, 103-114 (in Russian).

10. N.I. Podobaev and Ya.G. Avdeev, Specific Effects of Propargyl Alcohol and Propargyl Chloride on an Iron Electrode in Inorganic Acids, Prot. Met., 2000, 36, no. 3, 251-257. doi: 10.1007/BF02758401

11. N.I. Podobaev and Ya.G. Avdeev, Convective Factor in the Net Current of Iron Cathode in Sulfuric and Hydrochloric Solutions with Propargyl Alcohol and Propargyl Chloride, Prot. Met., 2001, 37, no. 2, 2001, 148-150. doi: 10.1023/A:1010374005175

12. N.I. Podobaev, V.E. Novikov and A.G. Voskresenskii, Izuchenie zashchitnogo deistviya nekotorykh proizvodnykh propargilovogo spirta i produktov ikh khimicheskikh prevrashchenii pri korrozii stali $\mathrm{v}$ solyanoi kislote (Study of the protective effect of certain derivatives of propargyl alcohol and the products of their chemical transformations during corrosion of steel in hydrochloric acid), Russ. J. Appl. Chem. (Zhurnal prikladnoy khimii), 1974, 47, no. 2, 370-374 (in Russian).

13. Z.M. Tsalikova, Sintez $i$ issledovanie svoistv atsetilenovykh efirov. Avtoreferat dissertatsii kandidata khimicheskih nauk. (Synthesis and study of the properties of acetylenic ethers. Author's abstract of PhD dissertation in Chemistry), M. Azizbekov Azerbaijan Oil and Chemistry Institute, Baku, 1974, 31 (in Russian).

14. S.Z. Israfilova, Sintez nekotorykh predel'nykh i nepredel'nykh efirov fosfinovykh kislot $\mathrm{i}$ ikh primenenie $\mathrm{v}$ kachestve ingibitorov korrozii stali v kisloy srede, Avtoreferat dissertatsii kandidata khimicheskih nauk (Synthesis of some saturated and unsaturated phosphinic acid esters and their use as corrosion inhibitors of steel in an acidic environment), Author's abstract of PhD dissertation in Chemistry, Yu.G. Mamedalieva Institute of Petrochemical Processes, Academy of Sciences of the Azerbaijan SSR, Baku, 1965, 24 (in Russian).

15. S.F. Karayev, S.T. Kaziyeva and I.A. Shikhiyev, Vysokotemperaturnye ingibitory korrozii stali $\mathrm{v}$ rastvorakh solyanoi kisloty (High-temperature steel corrosion inhibitors in hydrochloric acid solutions), Korroziya $i$ zashchita $v$ neftegazovoi promyshlennosti (Corrosion and protection in the oil and gas industry), 1978, no. 2, 10-11 (in Russian).

16. Z.F. Mirzayeva, F.K. Kurbanov, A. Ikramov, Kh.A. Khamrabayeva and G.A. Abdullayev, Vliyanie atsetilenovykh soedinenii na kislotnuyu korroziyu metallov gruppy zheleza (The effect of acetylene compounds on acid corrosion of metals of the iron group), Zashch. Met. (Protection of metals), 1984, 20, no. 1, 133-134 (in Russian).

17. S. Vishwanatham and N. Haldar, Furfuryl alcohol as corrosion inhibitor for N80 steel in hydrochloric acid, Corros. Sci., 2008, 50, 2999-3004. doi: 10.1016/j.corsci.2008.08.005

18. D. Jayaperumal, Effects of alcohol-based inhibitors on corrosion of mild steel in hydrochloric acid, Mater. Chem. Phys., 2010, 119, 478-484. doi: 10.1016/j.matchemphys.2009.09.028 
19. M.G. Veliev, N.M. Agaev, M.I. Shatirova, A.Z. Chalabieva and G.D. Geidarova, Synthesis diacetylenic ethers with terminal acetylenic bonds and studying them as inhibitors of steel corrosion in hydrochloric acid, Russ. J. Appl. Chem., 2010, 83, $1957-$ 1961. doi: $10.1134 / \mathrm{S} 1070427210110121$

20. N.M. Agaev, M.G. Veliev, G.D. Geidarova, A.Z. Chalabieva, E.G. Akperova, Z.A. Takhmazova and M.I. Shatirova, Funktsional'nye zameshchennye allilatsetilenyingibitory kislotnoi korrozii stali (Functional substituted allylacetylenes - acid corrosion inhibitors of steel), Zashch. Met. (Protection of metals), 1996, 32, no. 1, 101-103 (in Russian).

21. M.G. Veliev, M.I. Shatirova, G.D. Geidarova and F.M. Aliyeva, Aminosoderzhashchie atsetileny-ingibitory kislotnoi korrozii stali (Amino-containing acetylenes-acid corrosion inhibitors of steel), Korroz.: mater., zashch. (Corrosion: Materials, Protection), 2016, no. 5, 22-26 (inRussian).

22. A. Frignani, C. Monticelli, F. Zucchi and G. Trabanelli, Acetylenic alcohols as inhibitors of iron acid corrosion. Improvement of the inhibition efficiency of a class of substances based on their action mechanism, Int. J. Corros. Scale Inhib., 2014, 3, no. 2, 105-119. doi: $\underline{10.17675 / 2305-6894-2014-3-2-105-119}$

23. Q. Yu, X. Jiang, L. Zhou, Y. Liao, M. Duan, H. Wang and Q. Pu, Synthesis and Anticorrosion for X70 Steel of Propynol Derivatives in Acid Medium, J. Mater. Environ. Sci., 2014, 5, no. 1, 13-32.

24. F. El-Hajjaji, R.A. Belkhmima, B. Zerga, M. Sfaira, M. Taleb, M. Ebn Touhami and B. Hammouti, Time and Temperature Elucidation on Steel Corrosion Inhibition by 3methyl-1-prop-2-ynylquinoxalin-2(1H)-one in Molar Hydrochloric Acid: Part 2, J. Mater. Environ. Sci., 2014, 5, no. 1, 263-270.

25. J. Hmimou, A. Rochdi, R. Touir, M. Ebn Touhami, E.H. Rifi, A. El Hallaoui, A. Anouar and D. Chebab, Study of corrosion inhibition of mild steel in acidic medium by 2propargyl-5-p-chlorophenyltetrazole: Part I, J. Mater. Environ. Sci., 2012, 3, no. 3, 543550 .

26. S.A. Ali, H.A. Al-Muallem, M.T. Saeed and S.U. Rahman, Hydrophobic-tailed bicycloisoxazolidines: A comparative study of the newly synthesized compounds on the inhibition of mild steel corrosion in hydrochloric and sulfuric acid media, Corros. Sci., 2008, 50, no. 3, 664-675. doi: 10.1016/j.corsci.2007.10.010

27. S. Tu, X. Jiang, L. Zhou, M. Duan, H. Wang and X. Jiang, Synthesis of N-alkyl-4-(4hydroxybut-2-ynyl) pyridinium bromides and their corrosion inhibition activities on X70 steel in $5 \mathrm{M} \mathrm{HCl}$, Corros. Sci., 2012, 65, 13-25. doi: 10.1016/j.corsci.2012.07.022

28. M.A.J. Mazumder, H.A. Al-Muallem, M. Faiz and S.A. Ali, Design and synthesis of a novel class of inhibitors for mild steel corrosion in acidic and carbon dioxide-saturated saline media, Corros. Sci., 2014, 87, 187-198. doi: 10.1016/j.corsci.2014.06.026 
29. S.A. Ali, S.M.J. Zaidi, A.M.Z. El-Sharif and A.A. Al-Taq, Cyclopolymers from N,Ndiallyl-N-propargyl-(12-N'-formylamino)-1-dodecylammonium chloride and their use as inhibitors for mild steel corrosion, Polym. Bull., 2012, 69, 491-507. doi: $\underline{10.1007 / \mathrm{s} 00289-012-0765-3}$

30. M.G. Veliev, N.M. Agaev, M.I. Shatirova, A.Z. Chalabieva, G.D. Geidarova and S.S. Alieva, Allylacetylenes and Their Derivatives as Inhibitors of Steel Corrosion in Sulfuric Acid, Russ. J. Appl. Chem., 2006, 79, no. 11, 1829-1834. doi: $\underline{10.1134 / \mathrm{S} 1070427206110176}$

31. E. Barmatov, T. Hughes, J. Geddes and M. Nagl, Research on Corrosion Inhibitors for Acid Stimulation, CORROSION 2012, 11-15 March, 2012, Salt Lake City, Utah, NACE International, NACE-2012-1573.

32. R.A. Shank and T.R. McCartney, Comparative Study of Commercially Available Propargyl Alcohol-Free Corrosion Inhibitors for Hydrochloric Acid Systems, CORROSION 2013, 17-21 March, 2013, Orlando, Florida, NACE International, NACE2013-2760.

33. E. Barmatov, T. Hughes and M. Nagl, Performance of Organic Corrosion Inhibitors on Carbon Steels and High Alloys in 4 M Hydrochloric Acid, CORROSION 2015, 15-19 March, 2015, Dallas, Texas, NACE International, NACE-2015-5893.

34. Ya.G. Avdeev, Yu.I. Kuznetsov and A.K. Buryak, Inhibition of steel corrosion by unsaturated aldehydes in solutions of mineral acids, Corros. Sci., 2013, 69, 50-60. doi: 10.1016/j.corsci.2012.11.016

35. J. Gao, Y. Weng, Salitanate, F. Li and Y. Hong, Corrosion inhibition of $\alpha, \beta$-unsaturated carbonyl compounds on steel in acid medium, Pet. Sci., 2009, 6, 201-207. doi: 10.1007/s12182-009-0032-X

36. M.A. Quraishi, N. Sardar and H. Ali, A Study of Some New Acidizing Inhibitors on Corrosion of N-80 Alloy in 15\% Boiling Hydrochloric Acid, Corrosion, 2002, 58, no. 4, 317-321. doi: $10.5006 / 1.3287679$

37. A.R. Sathiya Priya, V.S. Muralidharan and A. Subramania, Development of Novel Acidizing Inhibitors for Carbon Steel Corrosion in 15\% Boiling Hydrochloric Acid, Corrosion, 2008, 64, no. 6, 541-552. doi: 10.5006/1.3278490

38. M.A. Quraishi and D. Jamal, Dianils: New and Effective Corrosion Inhibitors for OilWell Steel (N-80) and Mild Steel in Boiling Hydrochloric Acid, Corrosion, 2000, 56, no. 2, 156-160. doi: 10.5006/1.3280531

39. M.A. Quaraishi, D. Jamal and M.T. Saeed, Fatty acid derivatives as corrosion inhibitors for mild steel and oil-well tubular steel in $15 \%$ boiling hydrochloric acid, J. Am. Oil Chem. Soc., 2000, 77, 265-268. doi: 10.1007/s11746-000-0043-3

40. F.B. Growcock, Corrosion Kinetics of J55 Steel in Hydrochloric Acid Inhibited with Benzoyl Allyl Alcohol, Corrosion, 1989, 45, no. 5, 393-401. doi: 10.5006/1.3582034 
41. M. Finšgar and J. Jackson, Application of corrosion inhibitors for steels in acidic media for the oil and gas industry: A review, Corros. Sci., 2014, 86, 17-41. doi: 10.1016/j.corsci.2014.04.044

42. S.A. Umoren and M.M. Solomon, Effect of halide ions on the corrosion inhibition efficiency of different organic species-A review, J. Ind. Eng. Chem., 2015, 21, 81-100. doi: 10.1016/j.jiec.2014.09.033

43. Yu.I. Kuznetsov, Physicochemical aspects of metal corrosion inhibition in aqueous solutions, Russ. Chem. Rev., 2004, 73, no. 1, 75-87. doi: 10.1070/RC2004v073n01ABEH000864

44. Z. Wang, T. Wang, J. Zhu, L. Wei, Y. Shen, N. Li and J. Hu, Synergistic effect and mechanism of copper corrosion inhibition using cinnamaldehyde and vanillin in $\mathrm{HCl}$ solution: An experimental and theoretical approach, Colloids Surf., A, 2019, 563, 246254. doi: 10.1016/j.colsurfa.2018.12.012

45. F.K. Kurbanov and A.K. Iskhakov, Issledovanie ingibitornykh svoistv vtorichnykh atsetilenovykh spirtov pri korrozii uglerodistykh stalei v solyanoi kislote (Investigation of the inhibitory properties of secondary acetylene alcohols during corrosion of carbon steels in hydrochloric acid), Zhurnal Prikladnoy Khimii (Journal of Applied Chemistry), 1982, 55, no. 1, 99-103 (in Russian).

46. A.K. Iskhakov, Sintez i issledovanie ingibiruyushchikh svoistv i mekhanizma deistviya vtorichnykh atsetilenovykh spirtov pri korrozii uglerodistykh staley v kislykh sredakh. Avtoreferat dissertatsii kandidata khimicheskih nauk (Synthesis and study of the inhibitory properties and mechanism of action of secondary acetylene alcohols in the corrosion of carbon steels in acidic environments. Author's abstract of a PhD dissertation in Chemistry), Institute of Physical Chemistry, USSR Academy of Sciences, Moscow, 1986, 17 p. (in Russian).

47. A.K. Iskhakov and F.K. Kurbanov, Ingibitory kislotnoi korrozii, effektivnye pri povyshennoi temperature (Acid corrosion inhibitors effective at elevated temperatures), Zashch. Met. (Protection of Metals), 1983, 19, no. 6, 964-966 (in Russian).

48. S.H. Sanad, A.A. Ismail and N.A. Mahmoud, Inhibition effect of potassium iodide on corrosion of stainless steel in hydrochloric acid solution, J. Mater. Sci., 1992, 27, 57065712. doi: $\underline{10.1007 / \mathrm{BF} 01119726}$

49. A.A. Khadom, A.N. Abd and N.A. Ahmed, Potassium Iodide as a Corrosion Inhibitor of Mild Steel in Hydrochloric Acid: Kinetics and Mathematical Studies, J. Bio- TriboCorros., 2018, 4, 17. doi: 10.1007/s40735-018-0133-4

50. E. Aquino-Torres, R.L. Camacho-Mendoza, E. Gutierrez, J.A. Rodriguez, L. Feria, P. Thangarasu and J. Cruz-Borbollab, The influence of iodide in corrosion inhibition by organic compounds on carbon steel: Theoretical and experimental studies, Appl. Surf. Sci., 2020, 514, 145928. doi: 10.1016/j.apsusc.2020.145928

51. E.A. Noor and A.H. Al-Moubaraki, Thermodynamic study of metal corrosion and inhibitor adsorption processes in mild steel/1-methyl-4[4'(-X)-styryl pyridinium 
iodides/hydrochloric acid systems, Mater. Chem. Phys., 2008, 110, no. 1, 145-154. doi: 10.1016/j.matchemphys.2008.01.028

52. K.R. Ansari, D.S. Chauhan, M.A. Quraishi and T.A. Saleh, Bis(2-aminoethyl)aminemodified graphene oxide nanoemulsion for carbon steel protection in $15 \% \mathrm{HCl}$ : Effect of temperature and synergism with iodide ions, J. Colloid Interface Sci., 2020, 564, 124133. doi: $10.1016 /$ j.jcis.2019.12.125

53. M.M. Solomon, S.A. Umoren, M.A. Quraishi, D.B. Tripathy and E.J. Abai, Effect of akyl chain length, flow, and temperature on the corrosion inhibition of carbon steel in a simulated acidizing environment by an imidazoline-based inhibitor, J. Pet. Sci. Eng., 2020, 187, 106801. doi: 10.1016/j.petrol.2019.106801

54. I.B. Obot, S.A. Umoren and N.K. Ankah, Pyrazine derivatives as green oil field corrosion inhibitors for steel, J. Mol. Liq., 2019, 277, 749-761. doi: 10.1016/j.molliq.2018.12.108

55. S. Cao, D. Liu, H. Ding, J. Wang, H. Lu and J. Gui, Corrosion inhibition effects of a novel ionic liquid with and without potassium iodide for carbon steel in $0.5 \mathrm{M} \mathrm{HCl}$ solution: An experimental study and theoretical calculation, J. Mol. Liq., 2019, 275, 729-740. doi: 10.1016/j.molliq.2018.11.115

56. E. Ituen, A. James, O. Akaranta and S. Sun, Eco-friendly corrosion inhibitor from Pennisetum purpureum biomass and synergistic intensifiers for mild steel, Chin. J. Chem. Eng., 2016, 24, no. 10, 1442-1447. doi: 10.1016/j.cjche.2016.04.028

57. I.B. Obot and A. Madhankumar, Synergistic effect of iodide ion addition on the inhibition of mild steel corrosion in $1 \mathrm{M} \mathrm{HCl}$ by 3-amino-2-methylbenzylalcohol, Mater. Chem. Phys., 2016, 177, 266-275. doi: 10.1016/j.matchemphys.2016.04.027

58. M. Jokar, T.S. Farahani and B. Ramezanzadeh, Electrochemical and surface characterizations of morus alba pendula leaves extract (MAPLE) as a green corrosion inhibitor for steel in $1 \mathrm{M} \mathrm{HCl}$, J. Taiwan Inst. Chem. Eng., 2016, 63, 436-452. doi: 10.1016/j.jtice.2016.02.027

59. M.A. Hegazy, A.S. El-Tabei and H.M. Ahmed, Synthesis of nonionic surfactants and their inhibitive action on carbon steel in hydrochloric acid, Corros. Sci., 2012, 64, 115125. doi: $10.1016 /$ j.corsci.2012.07.004

60. S.A. Umoren, M.M. Solomon, S.A. Ali and H.D.M. Dafalla, Synthesis, characterization, and utilization of a diallylmethylamine-based cyclopolymer for corrosion mitigation in simulated acidizing environment, Mater. Sci. Eng.: C, 2019, 100, 897-914. doi: $\underline{10.1016 / \text { j.msec.2019.03.057 }}$

61. B.D.B. Tiu and R.C. Advincula, Polymeric corrosion inhibitors for the oil and gas industry: Design principles and mechanism, React. Funct. Polym., 2015, 95, 25-45. doi: 10.1016/j.reactfunctpolym.2015.08.006

62. V.S. Saji, A Review on Recent Patents in Corrosion Inhibitors, Recent Pat. Corros. Sci., 2010, 2, 6-12. 
63. A. Singh, E.E. Ebenso and M.A. Quraishi, Corrosion Inhibition of Carbon Steel in $\mathrm{HCl}$ Solution by Some Plant Extracts, Int. J. Corros., 2012, 897430. doi: $10.1155 / 2012 / 897430$

64. S.A. Abd El-Maksoud, The Effect of Organic Compounds on the Electrochemical Behaviour of Steel in Acidic Media. A review, Int. J. Electrochem. Sci., 2008, 3, 528-555.

65. S.A. Umoren and M.M. Solomon, Recent Developments on the Use of Polymers as Corrosion Inhibitors-A Review, Open Mater. Sci. J., 2014, 8, 39-54. doi: $\underline{10.2174 / 1874088 X 01408010039}$

66. M. Goyal, S. Kumar, I. Bahadur, C. Verma and E.E. Ebenso, Organic corrosion inhibitors for industrial cleaning of ferrous and nonferrous metals in acidic solutions: A review, J. Mol. Liq., 2018, 256, 565-573.doi: 10.1016/j.molliq.2018.02.045

67. Ya.G. Avdeev, Nitrogen-containing six-membered heterocyclic compounds as corrosion inhibitors for metals in solutions of mineral acids - A review, Int. J. Corros. Scale Inhib., 2018, 7, no. 4, 460-497. doi: 10.17675/2305-6894-2018-7-4-1

68. K. Rasheeda, Vijaya D.P. Alva, P.A. Krishnaprasad and S. Samshuddin, Pyrimidine derivatives as potential corrosion inhibitors for steel in acid medium-An overview, Int. J. Corros. Scale Inhib., 2018, 7, no. 1, 48-61. doi: 10.17675/2305-6894-2018-7-1-5

69. I.B. Obot, A. Meroufel, I.B. Onyeachu, A. Alenazi and A.A. Sorour, Corrosion inhibitors for acid cleaning of desalination heat exchangers: Progress, challenges and future perspectives, J. Mol. Liq., 2019, 296, 111760. doi: 10.1016/j.molliq.2019.111760

70. S.A. Umoren, M.M. Solomon, I.B. Obot and R.K. Sulieman, A critical review on the recent studies on plant biomaterials as corrosion inhibitors for industrial metals, J. Ind. Eng. Chem., 2019, 76, 91-115. doi: 10.1016/j.jiec.2019.03.057

71. N.I. Podobayev and V.V. Vasil'yev, Issledovanie zashchitnogo deistviya azotsoderzhashchikh i atsetilenovykh ingibitorov korrozii stali I ikh smesey v solyanoi kislote $\mathrm{v}$ zavisimosti ot temperatury $\left(\right.$ do $250^{\circ} \mathrm{C}$ ) i davleniya (do $700 \mathrm{~atm}$.) (Investigation of the protective effect of nitrogen-containing and acetylenic corrosion inhibitors of steel and their mixtures in hydrochloric acid as a function of temperature (up to $250^{\circ} \mathrm{C}$ ) and pressure (up to $700 \mathrm{~atm}$.)), Ingibitory Korrozii Metallov. Sbornik no. 3 (Metal corrosion inhibitors. Collection no. 3), Moscow, MGPI im. V.I. Lenina, 1969, 72-82 (in Russian).

72. N.I. Podobayev and V.V. Vasil'yev, Zashchitnoe deystvie azotsoderzhashchikh i atsetilenovykh ingibitorov korrozii stali $\mathrm{v}$ solyanoi kislote $\mathrm{v}$ zavisimosti ot temperatury i davleniya (The protective effect of nitrogen-containing and acetylene corrosion inhibitors of steel in hydrochloric acid depending on temperature and pressure), Zashch. Met. (Protection of Metals), 1969, 5, no. 1, 19-26.

73. Ya.G. Avdeev and N.I. Podobaev, The Role of Acrolein in the Inhibition of the Acid Corrosion of Iron with Propargyl Alcohol, Prot. Met., 2005, 41, no. 6, 592-596. doi: $\underline{10.1007 / \mathrm{s} 11124-005-0086-0}$ 
74. S.A. Umoren and M.M. Solomon, Synergistic corrosion inhibition effect of metal cations and mixtures of organic compounds: A Review, J. Environ. Chem. Eng., 2017, 5, no. 1, 246-273. doi: 10.1016/j.jece.2016.12.001

75. Ya.G. Avdeev, Yu.I. Kuznetsov, M.V. Tyurina and A.Yu. Luchkin, Vliyanie kationov metallov na zashchitnoe deistvie azotsoderzhashchikh ingibitorov kislotnoi korrozii (The effect of metal cations on the protective effect of nitrogen-containing acid corrosion inhibitors), Korroz.: mater., zashch. (Corrosion: Materials, Protection), 2012, no. 8, 31-36 (in Russian).

76. H.M. Abd El-Lateef, Corrosion inhibition characteristics of a novel salycilidene isatin hydrazine sodium sulfonate on carbon steel in $\mathrm{HCl}$ and a synergistic nickel ions additive: A combined experimental and theoretical perspective, Appl. Surf. Sci., 2020, 501, 144237. doi: 10.1016/j.apsusc.2019.144237

77. X. Li, S. Deng, H. Fu and G. Mu, Synergistic inhibition effect of rare earth cerium(IV) ion and 3,4-dihydroxybenzaldehye on the corrosion of cold rolled steel in $\mathrm{H}_{2} \mathrm{SO}_{4}$ solution, Corros. Sci., 2009, 51, no. 11, 2639-2651. doi: 10.1016/j.corsci.2009.06.047

78. X. Li, S. Deng, H. Fu and G. Mu, Synergistic inhibition effect of rare earth cerium(IV) ion and sodium oleate on the corrosion of cold rolled steel in phosphoric acid solution, Corros. Sci., 2010, 52, no. 4, 1167-1178. doi: 10.1016/j.corsci.2009.12.017

79. X. Li, S. Deng, H. Fu and G. Mu, Synergistic inhibition effect of rare earth cerium(IV) ion and anionic surfactant on the corrosion of cold rolled steel in $\mathrm{H}_{2} \mathrm{SO}_{4}$ solution, Corros. Sci., 2008, 50, no. 9, 2635-2645. doi: 10.1016/j.corsci.2008.06.026

80. S. Cheng, S. Chen, T. Liu, X. Chang and Y. Yin, Carboxymethylchitosan $+\mathrm{Cu}^{2+}$ mixture as an inhibitor used for mild steel in $1 \mathrm{M} \mathrm{HCl}$, Electrochim. Acta, 2007, 52, no. 19, 5932-5938. doi: 10.1016/j.electacta.2007.03.038

81. B.R. Keeney and J.W. Johnson, Inhibited treating acid, US Patent 3,773,465, Halliburton Company, Duncan, Okla, 1973.

82. M.L. Walker, Method and composition for acidizing subterranean formations, US Patent 4,498,997, Halliburton Company, Duncan, Okla, 1985.

83. W.W. Frenier and D.G. Hill, Green inhibitors development and applications for aqueous systems, in Reviews on Corrosion Inhibitor Science and Technology, Ed.: A. Raman, USA, Houston, Texas: NACE International, 2004, 3, 6-1-6-40.

84. Z.A. Foroulis, Cinnamic aldehyde inhibitors, US Patent 3,589,860, ExxonMobil Research and Engineering Co, 1971.

85. W.W. Frenier and F.B. Growcock, Mixtures of $\alpha, \beta$-unsaturated aldehides and surface active agents used as corrosion inhibitors in aqueous fluids, US Patent 4,734,259, Dowell Schlumberger Incorporated, Tulsa, Okla, 1988.

86. W.W. Frenier, Process and composition for inhibiting high-temperature iron and steel corrosion, US Patent 5,096,618, Dowell Schlumberger Incorporated, Tulsa, Okla, 1992. 
87. D.G. Hill and H. Romijn, Reduction of Risk to the Marine Environment From Oilfield Chemicals: Environmentally Improved Acid Corrosion Inhibition for Well Stimulation, in Conference Paper: Corrosion, 2000, 26-31 March, Orlando, Florida, NACE International, NACE-00342.

88. R.J. Jasinski and W.W. Frenier, Process and composition for protecting chrome steel, US Patent 5,120,471, Dowell Schlumberger Incorporated, Tulsa, Okla, 1992.

89. M.A. Vorderbruggen and D.A. Williams, Acid corrosion inhibitor, US Patent 6,117,364, Nalco/Exxon Energy Chemicals, L.P., Sugar Land, TeX, 2000.

90. J.M. Cassidy, C.E. Kiser and J.L. Lane, Corrosion inhibitor intensifier compositions and associated methods, US Patent 7,994,101B2, Halliburton Energy Services, Inc., Duncan, OK (US), 2011.

91. S. Ali, J.S. Reyes, M.M. Samuel and F.M. Auzerais, Self-diverting acid treatment with formic-acid-free corrosion inhibitor, US Patent 7,902,124 B2, Schlumberger Technology Corp., Sugar Land, TX (US), 2011.

92. F.B. Growcock, Inhibition of Steel Corrosion in $\mathrm{HCl}$ by Derivatives of Cinnamaldehyde: Part I. Corrosion Inhibition Model, Corrosion, 1989, 45, no. 12, 1003-1007. doi: $10.5006 / 1.3585007$

93. Ya.G. Avdeev, Yu.I. Kuznetsov and P.A. Belinskiy, Zashchita stali ot kislotnoi korrozii ingibitorami na osnove produktov kondensatsii pervichnykh aminov $\mathrm{i}$ al'degidov (Protection of steel against acid corrosion by inhibitors based on the condensation products of primary amines and aldehydes), Korroz.: mater., zashch. (Corrosion: Materials, Protection), 2009, no. 11, 20-26 (inRussian).

94. W.W. Frenier, F.B. Growcock and V.R. Lopp, $\alpha$-Alkenylphenones - A New Class of Acid Corrosion Inhibitors, Corrosion, 1988, 44, no. 9, 590-598. doi: 10.5006/1.3584970

95. G. Trabanelli, F. Zucchi and G. Brunoro, Inhibition of Corrosion resistant alloys in hot hydrochloric acid solutions, Mater. Corros., 1988, 39, 589-594. doi: 10.1002/maco.19880391206

96. E. Barmatov, T. Hughes and M. Nagl, Efficiency of film-forming corrosion inhibitors in strong hydrochloric acid under laminar and turbulent flow conditions, Corros. Sci., 2015, 92, 85-94. doi: 10.1016/j.corsci.2014.11.038

97. T. Kumar, S. Vishwanatham and E. Khan, Study on corrosion control of N80 steel in acid medium using mixed, Indian J. Chem. Technol., 2008, no. 3, 221-227.

98. K.D. Allabergenov and F.K. Kurbanov, Atsetilenovye soedineniya - ingibitory korrozii stali v sernoi kislote (Acetylene compounds are corrosion inhibitors of steel in sulfuric acid), Zashch. Met. (Protection of Metals), 1975, 15, 472-473 (in Russian).

99. Z.F. Mirzayeva, F.K. Kurbanov, A. Ikramov and Kh.A. Khamrabayeva, Izucheniye zashchitnykh svoistv atsetilenovykh soyedinenii pri korrozii metallov gruppy zheleza $\mathrm{v}$ sernoi kislote (A study of the protective properties of acetylenic compounds in the corrosion of iron group metals in sulfuric acid), Zhurnal Prikladnoy Khimii (Journal of Applied Chemistry), 1984, 57, no. 11, 2626-2628 (in Russian). 
100. N.I. Podobaev and Ya.G. Avdeev, The Effect of Several Anions and Inhibitors Mixed with Propargyl Alcohol on Electrode Reactions and Corrosion of Steel in Sulfuric Acid, Prot. Met., 2001, 37, no. 1, 13-17. doi: 10.1023/A:1004873231812

101. P. Kuteja, J. Vosta, J. Pancir and N. Hackerman, Electrochemical and Quantum Chemical Study of Propargyl Alcohol Adsorption on Iron, J. Electrochem. Soc., 1995, 142, no. 6, 1847-1850. doi: $10.1149 / 1.2044204$

102. W.W. Frenier, F.B. Growcock and V.R. Lopp, Mechanisms of Corrosion Inhibitors Used in Acidizing Wells, SPE Prod. Eng., 1988, 3, no. 4, 584-590. doi: 10.2118/14092PA

103. A.S. Fouda, M.A. Elmorsi and A. Elmekkawy, Eco-friendly chalcones derivatives as corrosion inhibitors for carbon steel in hydrochloric acid solution, Afr. J. Pure Appl. Chem., 2013, 7, no. 10, 337-349. doi: 10.5897/AJPAC2013.0520

104. M.A. Quraishi and D. Jamal, Dianils as new and effective corrosion inhibitors for mild steel in acidic solutions, Mater. Chem. Phys., 2003, 78, 608-613. doi: 10.1016/S0254$\underline{0584(02) 00002-0}$

105. M. Farsak, H. Keles and M. Keles, A new corrosion inhibitor for protection of low carbon steel in $\mathrm{HCl}$ solution, Corros. Sci., 2015, 98, 223-232. doi: 10.1016/j.corsci.2015.05.036

106. K. Mallaiya, R. Subramaniam, S.S. Srikandan, S. Gowri, N. Rajasekaran and A. Selvaraj, Electrochemical characterization of the protective film formed by the unsymmetrical Schiff's base on the mild steel surface in acid media, Electrochim. Acta, 2011, 56, 3857-3863. doi: 10.1016/j.electacta.2011.02.036

107. G.W. Poling, Infrared Studies of Protective Films Formed by Acetylenic Corrosion Inhibitors, J. Electrochem. Soc., 1967, 114, no. 12, 1209-1214. doi: 10.1149/1.2426451

108. F.B. Growcock and V.R. Lopp, The inhibition of steel corrosion in hydrochloric acid with 3-phenyl-2-propyn-1-ol, Corros. Sci., 1988, 28, no. 4, 397-410. doi: 10.1016/0010938X(88)90059-5

109. F.B. Growcock, V.R. Lopp and R.J. Jasinski, Corrosion Protection of Oilfield Steel with 1-Phenyl-2-Propyn-1-ol, J. Electrochem. Soc., 1988, 135, no. 4, 823-827. doi: $\underline{10.1149 / 1.2095785}$

110. M. Bartos, S.D. Kapusta and N. Hackerman, A Study of Polymerization of Propargyl Alcohol on Steel, J. Electrochem. Soc., 1993, 140, no. 9, 2604-2605. doi: $\underline{10.1149 / 1.2220870}$

111. K. Aramaki and E. Fujioka, Surface-Enhanced Raman Scattering Spectroscopy Studies on the Inhibition Mechanism of Propargyl Alcohol for Iron Corrosion in Hydrochloric Acid, Corrosion, 1996, 52, no. 2, 83-91. doi: 10.5006/1.3292107

112. F.B. Growcock and V.R. Lopp, Film Formation on Steel in Cinnamaldehyde-Inhibited Hydrochloric Acid, Corrosion, 1988, 44, no. 4, 248-254. doi: 10.5006/1.3583933

113. N.I. Podobayev and V.I. Kotov, K voprosu o mekhanizme zashchitnogo deistviya atsetilenovykh soyedinenii pri korrozii stali v solyanoi kislote (To the question of the 
protective mechanism of acetylenic compounds during corrosion of steel in hydrochloric acid), in Uchenyye zapiski №340 (Scientific notes No. 340), Moscow, MGPI im. V.I. Lenina, 1971, 15-26 (in Russian).

114. N.I. Podobayev, V.I. Kotov and A.G. Voskresensky, O khimicheskom prevrashchenii dimetiletinilkarbinola pri korrozii stali v solyanoi kislote (On the chemical conversion of dimethylethinylcarbinol in the corrosion of steel in hydrochloric acid), in Uchenyye zapiski №340 (Scientific notes No. 340), Moscow, MGPI im. V.I. Lenina, 1971, 27-31 (in Russian).

115. A.K. Buryak, N.P. Platonova, I.S. Pytskiy and A.V. Ul'yanov, Mass-spektrometriya dlya issledovaniya korrozionnykh protsessov na poverkhnostyakh konstruktsionnykh materialov (Mass spectrometry for the study of corrosion processes on the surfaces of structural materials), Analitika (Analytics), 2019, 9, no. 2, 126-135 (in Russian). doi: 10.22184/2227-572X.2019.9.2.126.135

116. A.K. Buryak, I.S. Pytskiy, T.M. Serdyuk and A.V. Ul'yanov, Mass-spektrometriya dlya issledovaniya korrozii i ingibitorov korrozii (Mass spectrometry for the study of corrosion and corrosion inhibitors), Korroz.: mater., zashch. (Corrosion: Materials, Protection), 2011, no. 4, 6-12 (inRussian).

117. Ya.G. Avdeev, Yu.I. Kuznetsov and V.M. Larionova, Ob ingibirovanii al'degidami korrozii stali $\mathrm{v}$ rastvorakh mineral'nykh kislot (On the inhibition of steel corrosion by aldehydes in solutions of mineral acids), Korroz.: mater., zashch. (Corrosion: Materials, Protection), 2010, no. 10, 31-41 (in Russian).

118. J.O'M. Bockris and B. Yang, The Mechanism of Corrosion Inhibition of Iron in Acid Solution by Acetylenic Alcohols, J. Electrochem. Soc., 1991, 138, 2237-2252. doi: $\underline{10.1149 / 1.2085956}$

119. N.I. Podobaev and Ya.G. Avdeev, The Effect of Hydrogenation on the Anodic Dissolution of Iron and Its Inhibition by Propinol in Hydrochloric Acid, Prot. Met., 1999, 35, no. 5, 484-488.

120. N.I. Podobaev and Ya.G. Avdeev, Joint Effect of Hydrogen and Propargyl Alcohol on the Kinetics of Electrode Reactions and Iron Corrosion Rate in Hydrochloric Acid, Prot. Met., 2000, 36, no. 2, 180-184. doi: 10.1007/BF02758343

121. F.B. Mainier, H.N. Farneze, L.F. Serrão, B. Tannus de Oliveira and B.F. Nani, Performance of Stainless Steel AISI 317L in Hydrochloric Acid with the Addition of Propargyl Alcohol, Int. J. Electrochem. Sci., 2018, 13, 3372-3381. doi: 10.20964/2018.04.02

122. F.B. Mainier, P.I.F.S. Pegoraro and M.V. Santoro, Propargyl alcohol as a corrosion inhibitor for AISI 304L stainless steel in hydrochloric acid, Int. J. Adv. Eng. Res. Sci. (IJAERS), 2018, 5, no. 10, 168-172. doi: 10.22161/ijaers.5.10.22 
123. K. Babic-Samardzija, C. Sandu, N. Hackerman and A.R. Barron, Inhibitive properties, adsorption and surface study of butyn-1-ol and pentyn-1-ol alcohols as corrosion inhibitors for iron in $\mathrm{HCl}$, J. Mater. Chem., 2005, 15, no. 19, 1908-1916. doi: 10.1039/b416202a

124. M.A. Quraishi，D. Jayaperumal，P. Subramanian, M. Natesan, G. Venkatachari and K. Balakrishnan, A study of corrosion inhibitors on oil well steel and mild steel in boiling hydrochloric acid, Bull. Electrochem., 1996, 12, no. 9, 526-528.

125. S.M. Zakir Hossain, A. Al-Shater, S.A. Kareem, A. Salman, R.A. Ali, H. Ezuber, M.M. Hossain and S.A. Razzak, Cinnamaldehyde as a Green Inhibitor in Mitigating AISI 1015 Carbon Steel Corrosion in HCl, Arab. J. Sci. Eng., 2019, 44, 5489-5499. doi: 10.1007/s13369-019-03793-y

126. G. Cabello, G.P. Funkhouser, J. Cassidy, C.E. Kiser, J. Lane and A. Cuesta, CO and trans-cinnamaldehyde as corrosion inhibitors of I825, L80-13Cr and N80 alloys in concentrated $\mathrm{HCl}$ solutions at high pressure and temperature, Electrochim. Acta, 2013, 97, 1-9. doi: 10.1016/j.electacta.2013.03.011

127. S. Abd El Wanees and E.E. Abd El Aal, N-Phenylcinnamimide and some of its derivatives as inhibitors for corrosion of lead in $\mathrm{HCl}$ solutions, Corros. Sci., 2010, 52, 338-344. doi: 10.1016/j.corsci.2009.09.022

128. H. Keles and M. Keles, Electrochemical investigation of a Schiff base synthesized by cinnamaldehyde as corrosion inhibitor on mild steel in acidic medium, Res. Chem. Intermed., 2014, 40, 193-209. doi: 10.1007/s11164-012-0955-5

129. N.I. Podobaev and Ya.G. Avdeev, Temperature and Time Effects on the Acid Corrosion of Steel in the Presence of Acetylenic Inhibitor, Prot. Met., 2001, 37, no. 6, 529-533. doi: 10.1023/A:1012855211234

130. T. Kristóf and T. Salamon, Electrochemical investigation of the inhibiting properties of 2-propyn-1-ol on carbon steel in hydrochloric acid, Mater. Corros., 1990, 41, 519-522. doi: $10.1002 /$ maco.19900410906

131. N.I. Podobaev and Ya.G. Avdeev, Effect of the Molecule Structure of Acetylene Compounds on the Kinetics of the Electrode Reactions of Iron in Hydrochloric and Sulfuric Acid, Prot. Met., 2002, 38, no. 1, 45-50. doi: 10.1023/A:1013852801262

132. F.K. Kurbanov and N.I. Podobaev, Issledovanie vliyaniya davleniya na elektrodnyi potentsial i polyarizatsiyu stali $\mathrm{v}$ solyanoi kislote $\mathrm{v}$ prisutstvii ingibitorov (Investigation of the effect of pressure on the electrode potential and polarization of steel in hydrochloric acid in the presence of inhibitors), in Ingibitory Korrozii Metallov (Metal Corrosion Inhibitors), Ed.: S.A. Balezin, Publishing House "Sudostroyeniye", Moscow, 1965, 95-99 (in Russian).

133. N.I. Podobaev and V.V. Vasil'yev, K voprosu o mekhanizme deistviya ingibitorov kislotnoi korrozii pri vysokikh davleniyakh i temperaturakh (On the mechanism of action of acid corrosion inhibitors at high pressures and temperatures), in Ingibitory korrozii 
metallov (Metal Corrosion Inhibitors), MGPI im. V.I. Lenina, Moscow, 1969, Issue 3, 83-85 (in Russian).

134. F.B. Growcock, W.W. Frenier and P.A. Andreozzi, Inhibition of Steel Corrosion in $\mathrm{HCl}$ by Derivatives of Cinnamaldehyde: Part II. Structure-Activity Correlations, Corrosion, 1989, 45, no. 12, 1007-1015. doi: $10.5006 / 1.3585008$

135. G. Gece, The use of quantum chemical methods in corrosion inhibitor studies, Corros. Sci., 2008, 50, 2981-2992. doi: 10.1016/j.corsci.2008.08.043

136. G. Lendvay-Gyorik, G. Meszaros, B. Lengyel and G. Lendvay, Electrochemical and quantum chemical studies on the formation of protective films by alkynols on iron, Corros. Sci., 2003, 45, 1685-1702. doi: 10.1016/S0010-938X(03)00019-2

137. K.F. Khaled and N.S. Abdel-Shafi, Quantitative Structure and Activity Relationship Modeling Study of Corrosion Inhibitors: Genetic Function Approximation and Molecular Dynamics Simulation Methods, Int. J. Electrochem. Sci., 2011, 6, 40774094.

138. Ya.G. Avdeev and Yu.I. Kuznetsov, Osobennosti deistviya produktov kondensatsii benzilamina s $\alpha, \beta$-nenasyshchennymi al'degidami na stal' $\mathrm{v}$ rastvorakh mineral'nykh kislot (Specific features of the action of condensation products of benzylamine with $\alpha, \beta$ unsaturated aldehydes on steel in solutions of mineral acids), Korroz.: mater., zashch. (Corrosion: Materials, Protection), 2009, no. 12, 4-11 (in Russian). 